\title{
MECANISMOS DE RESISTÊNCIA AO INSETICIDA METIDATION EM Amblyseius womersleyi SCHICHA, 1975 (ACARI: PHYTOSEIIDAE)
}

\section{MÁRIO EIDI SATO}

\author{
Engenheiro Agrônomo
}

Orientador: Prof. Dr. OCTAVIO NAKANO

Tese apresentada à Escola Superior de Agricultura "Luiz de Queiroz", Universidade de São Paulo, para obtenção do título de Doutor em Ciências, Área de Concentração: Entomologia.

P I R A C I C A B A

Estado de São Paulo - Brasil

Janeiro - 1999 
Dados Internacionais de Catalogação na Publicação (CIP) DIVISĀO DE BIBLIOTECA E DOCUMENTAÇĀO - Campus "Luiz de Queiroz"/USP

Sato, Mário Eidi

Mecanismos de resistência ao inseticida metidation em Amblyseius womers/eyi Schicha, 1975 (Acari: Phytoseiidae) / Mário Eidi Sato. - - Piracicaba, 1999. $69 \mathrm{p}$.

Tese (doutorado) - - Escola Superior de Agricultura Luiz de Queiroz, 1999. Bibliografia.

1. Ácaro-predador 2. Chá 3. Controle biológico 4. Inseticida organofosforado 5. Praga agrícola 6. Resistência ao pesticida 7. Seleção animal 1. Titulo 
Aos meus pais, Saburo e Tomiko, à minha esposa Catanina e filha Juliana, pelo amor e incentivo

DEDICO. 


\section{AGRADECIMENTOS}

Ao Prof. Dr. Octavio Nakano, pela orientação, amizade e estímulo no transcorrer do presente trabalho.

Ao Prof. Dr. Tadashi Miyata, da Universidade de Nagoya, Japão, pela orientação, amizade e auxilio na realização deste trabalho.

Ao Prof. Dr. Celso Omoto, pelo auxilio na elaboração do plano de tese e sugestões para a realização do presente trabalho.

Ao Instituto Biológico do Estado de São Paulo, pela oportunidade concedida para a realização do curso de Pós-Graduação e condução deste trabalho.

Ao $\mathrm{CNPq}$ pela bolsa concedida

Ao Dr. Akira Kawai, do Departamento de Agronomia do Chá/Instituto Nacional de Pesquisa de Vegetais, Plantas Ornamentais e Chá, Shizuoka, Japão, pelo fornecimento das populações de ácaros predadores.

À NOVARTIS, pelo fornecimento dos inseticidas $\left[{ }^{14} \mathrm{C}\right]$-metidation, metidation oxon e padrão.

Ao Prof. Dr. Gilberto J. de Moraes, pelo apoio e conhecimentos transmitidos. 
Aos professores do Departamento de Entomologia da ESALQ/USP, pelos conhecimentos transmitidos.

Aos professores e funcionários do Laboratório de Entomologia Aplicada da Universidade de Nagoya, pelo apoio no desenvolvimento do trabalho.

Ao estudante de mestrado, Yohei Kato, da Universidade de Nagoya, pelo auxilio na realização de diversos experimentos.

Aos pesquisadores e colegas do Instituto Biológico, Dr. Adalton Raga, Miguel Francisco de Souza Filho, Dalva Gabriel, Dra. Zuleide Alves Ramiro, Dr. Antonio Batista Filho e Dr. Valmir Antonio Costa, pela amizade e colaboração.

Aos colegas do Departamento de Entomologia da ESALQ/USP, pelo apoio e amizade

À todas as pessoas ou instituições que colaboraram direta ou indiretamente para a realização deste trabalho. 


\section{SUMÁRIO}

Página

LISTA DE FIGURAS........................................................................ viii

LISTA DE TABELAS....................................................................... ix

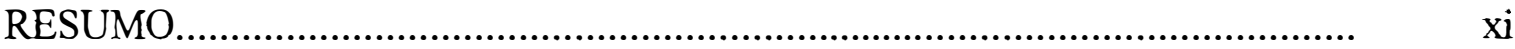

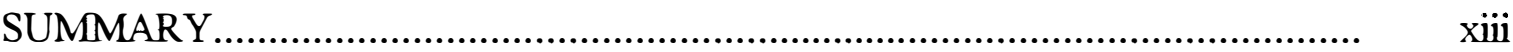

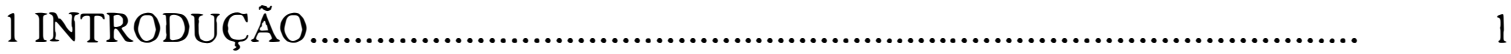

2 REVISÃO DE LITERATURA............................................................... 3

2.1 Amblyseius womersleyi Schicha (Acari: Phytoseiidae)................................ 3

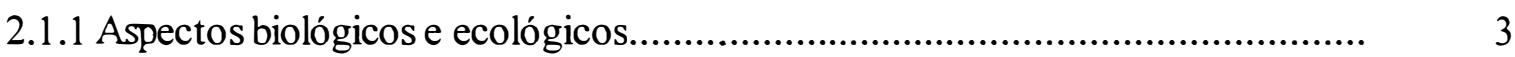

2.2. Resistência de inimigos naturais a pesticidas..............................................

2.3 Resistência de ácaros da familia Phytoseiidae a pesticidas........................... 5

2.4 Mecanismos de resistência....................................................................

3 MATERIAL E MÉTODOS.................................................................. 11

3.1 Populações de ácaros.......................................................................... 11

3.2 Criação de ácaros............................................................................... 12

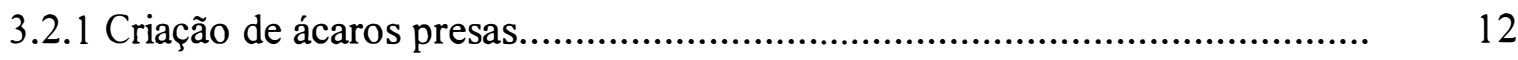

3.2.2 Criação de ácaros predadores........................................................... 12

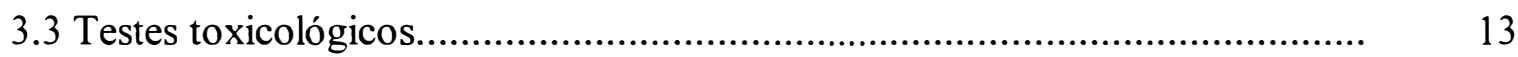

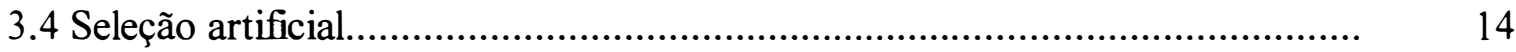

3.4.1 Seleção artificial para resistência....................................................... 14

3.4.2 Seleção artificial para suscetibilidade....................................................... 14

3.5 Testes toxicológicos com tubo de vidro e arena de folha............................ 15

3.5.1 Teste com tubo de vidro............................................................. 15

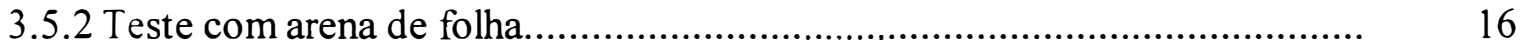

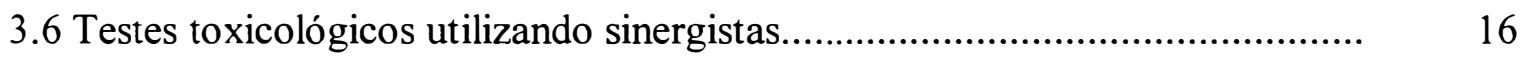

3.6.1 Teste 1 com sinergistas.................................................................... 16

3.6.1.1 Estimativa da "concentração subletal máxima" para sinergistas................ 17 


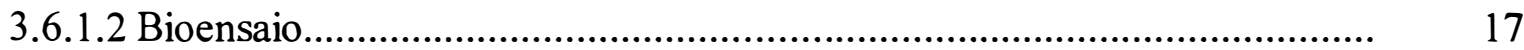

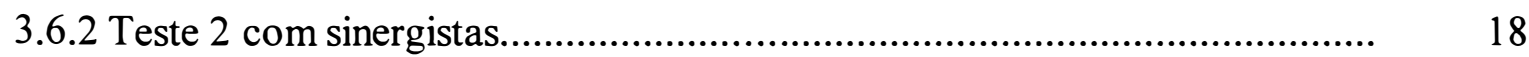

3.6.2.1 Estimativa da "concentração subletal máxima" para sinergistas.................. 18

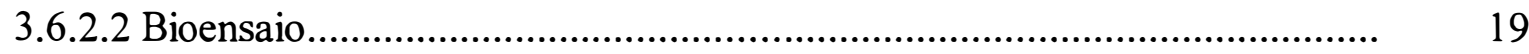

3.7 Alteração no alvo de ação............................................................................ 19

3.7.1 Preparo da enzima................................................................................. 19

3.7.2 Determinação da concentração de proteína..................................................... 20

3.7.3 Atividade de acetilcolinesterase .................................................................. 20

3.7.4 Teste de inibição.................................................................................. 21

3.8 Penetração cuticular..................................................................................... 22

3.9 Metabolismo "in vitro" de metidation.......................................................... 23

3.9.1 Determinação da concentração de proteína..................................................... 24

3.10 Testes toxicológicos com diferentes pesticidas............................................. 24

4 RESULTADOS E DISCUSSÃO............................................................ 26

4.1 Seleção artificial para resistência e suscetibilidade.............................................. 26

4.2 Testes toxicológicos com tubo de vidro e arena de folha............................... 29

4.3. Testes toxicológicos utilizando sinergistas..................................................... 31

4.3.1 Teste 1 com sinergistas........................................................................... 31

4.3.1.1 Estimativa da "concentração subletal máxima" para sinergistas.................. 31

4.3.1.2 Bioensaio .................................................................................... 33

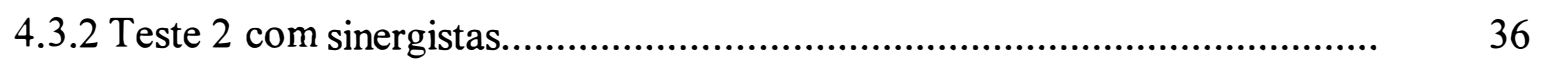

4.3.2.1 Estimativa da "concentração subletal máxima" para sinergistas.................. 36

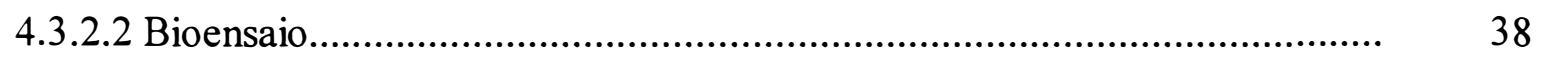

4.4 Alteração no alvo de ação........................................................................... 42

4.4.1 Atividade de acetilcolinesterase........................................................... 42

4.4.2 Teste de inibição...................................................................................

4.5 Penetração cuticular.................................................................................. 45

4.6 Metabolismo "in vitro" de metidation........................................................... 48

4.6.1 Concentração de proteína........................................................................... 51 
4.7 Testes toxicológicos com diferentes pesticidas............................................. 51

4.8 Considerações gerais.................................................................................. 53

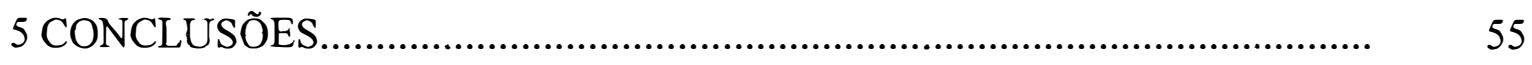

REFERÊNCIAS BIBLIOGRÁFICAS....................................................... 56 


\section{LISTA DE FIGURAS}

1 Linhas de mortalidade, obtidas com as populações suscetível (S) e resistente

Página (R) de Amblyseius womersleyi, tratadas com metidation, com ou sem o prétratamento com sinergistas (PBO a 2,11 mg/ml e PTPE a 0,062 mg/ml)........

2 Inibição de acetilcolinesterase por metidation oxon em homogeneizados de fềmeas de Amblyseius womersleyi, das populações suscetível e resistente......

$3 \quad\left[{ }^{14} \mathrm{C}\right]$-metidation detectado sobre a cutícula de Amblyseius womersleyi, em diferentes períodos após o tratamento por mergulho de fềmeas adultas das populações suscetível $(\mathrm{S})$ e resistente $(\mathrm{R})$ em solução inseticida. Média e desvio padrão das quantidades do inseticida. 


\section{LISTA DE TABELAS}

1 Seleção para resistência e suscetibilidade de duas populações de Amblyseius womersleyi a metidation. Número total de ácaros selecionados $\mathrm{e}$ mortalidade.

2 Seleção para resistência e suscetibilidade, de duas populações de Amblyseius womersleyi a metidation. Número total de ácaros utilizados para a obtenção das curvas de concentração-mortalidade; estimativa da $\mathrm{CL}_{50}(\mathrm{ppm})$ e intervalo de confiança (I.C.) a $95 \%$; coeficiente angular e erro padrão da média (EPM); Qui-quadrado $\left(\chi^{2}\right)$; grau de liberdade (G.L.)

3 Efeito de metidation, em duas populações (S e R) de Amblyseius womersleyi, colocando-se os ácaros em tubo de vidro de $10 \mathrm{~cm} \times 1,2 \mathrm{~cm}$ tratado internamente com metidation, ou em arena de folha de feijão tratada através de pulverização realizada diretamente sobre os ácaros. Número total de ácaros utilizados para a obtenção das curvas de concentração-mortalidade; estimativa da $\mathrm{CL}_{50}(\mathrm{ppm})$ e intervalo de confiança (I.C.) a 95\%; coeficiente angular e erro padrão da média (EPM); Qui-quadrado $\left(\chi^{2}\right)$; grau de liberdade (G.L.); razão de resistência (RR)

4 Estimativa da "concentração subletal máxima" para os sinergistas PBO (butóxido de piperonila), DEM (dietil maleato), DEF (S,S,S tributilfosforotritioato), em uma população suscetível de Amblyseius womersleyi a metidation.

5 Efeito de metidation, com ou sem sinergista, nas populações suscetível e resistente de Amblyseius womersleyi. Número total de ácaros utilizados para a obtenção das curvas de concentração-mortalidade; estimativa da $\mathrm{CL}_{50}(\mathrm{ppm})$ e intervalo de confiança (I.C.) a $95 \%$; coeficiente angular e erro padrão da média (EPM); Qui-quadrado $\left(\chi^{2}\right)$; grau de liberdade (G.L.); razão de resistência (RR); razão de sinergismo (RS)

6 Estimativa da "concentração subletal máxima" para os sinergistas PBO (butóxido de piperonila) e PTPE (2-propinil 2,3,6-triclorofenil eter), nas populações suscetível e resistente de Amblyseius womersleyi. 
7 Efeito de metidation, com ou sem sinergista (PBO, PTPE), em duas populações (R e $\mathrm{S}$ ) de Amblyseius womersleyi. Número total de ácaros utilizados para a obtenção das curvas de concentração-mortalidade; estimativa da $\mathrm{CL}_{50}$ (ppm) e intervalo de confiança (I.C.) a 95\%; coeficiente angular e erro padrão da média (EPM); Qui-quadrado $\left(\chi^{2}\right)$; grau de liberdade (G.L.); razão de resistência (RR); razão de sinergismo (RS).

8 Atividades de acetilcolinesterase ( $K \mathrm{~m}$ e $V \max )$ das populações de Amblyseius womersleyi suscetivel e resistente a metidation.

9 Inibição de acetilcolinesterase $\left(\mathrm{I}_{50}\right)$ em duas populações de Amblyseius womersleyi, utilizando metidation oxon como inibidor

$10 \quad\left[{ }^{14} \mathrm{C}\right]$-metidation detectado sobre a cutícula de Amblyseius womersleyi, em diferentes períodos após o tratamento por mergulho de fềmeas adultas das populações resistente e suscetível em solução inseticida. Radioatividade (dpm) detectada no líquido resultante da lavagem dos ácaros com hexano e desvio padrão.

11 Metabólitos solúveis em água após a incubação de $\left[{ }^{14} \mathrm{C}\right]$-metidation por $5 \mathrm{~h}$ em diferentes frações subcelulares de ácaros suscetíveis $(\mathrm{S})$ e resistentes $(\mathrm{R})$ de Amblyseius womersleyi.

12 Testes toxicológicos com diferentes pesticidas utilizando as populações resistente (R) e suscetível (S) de Amblyseius womersleyi. Número total de ácaros para a obtenção das curvas de concentração-mortalidade; estimativa da $\mathrm{CL}_{50}(\mathrm{ppm}$ ) e intervalo de confiança (I.C.) a 95\%; coeficiente angular e erro padrão da média (EPM); Qui-quadrado $\left(\chi^{2}\right)$; grau de liberdade (G.L.); razão de resistência (RR). 


\title{
MECANISMOS DE RESISTÊNCIA AO INSETICIDA METIDATION EM Amblyseius womersleyi SCHICHA, 1975 (ACARI: PHYTOSEIIDAE)
}

\author{
Autor: MÁRIO EIDI SATO \\ Orientador: Prof. Dr. OCTAVIO NAKANO
}

\section{RESUMO}

O ácaro predador Amblyseius womersleyi Schicha é um importante inimigo natural do ácaro Tetranychus kanzawai Kishida, considerado praga-chave da cultura do chá no Japão. Com o objetivo de estudar os mecanismos de resistência a metidation neste fitoseídeo, selecionou-se para o aumento da resistência ao inseticida, uma população resistente de $A$. womersleyi. Concomitantemente, realizou-se a seleção para o aumento da suscetibilidade, utilizando-se uma outra população, mais suscetível a metidation. Após quatro seleções para resistência e três seleções para suscetibilidade, houve um aumento na razão de resistência (R/S), ao nível de $\mathrm{CL}_{50}$, de 16 para 342 vezes. Estudou-se o efeito de alguns sinergistas (PBO, DEM e DEF) na toxicidade de metidation, sobre $A$. womersleyi. A razão de sinergismo (RS: $\mathrm{CL}_{50}$ sem sinergista/CL $\mathrm{L}_{50}$ com sinergista) mais alta foi obtida para PBO (inibidor de ofm, oxidases com funções múltiplas), com aumento de 12,3 vezes na toxicidade do inseticida, na população $\mathrm{R}$ deste predador. Realizou-se um segundo teste com sinergistas, desta vez utilizando PBO e PTPE (inibidor de ofm). A mais alta RS foi verificada para PTPE, com 59,3 vezes, para a população $\mathrm{R}$ de $A$. womersleyi. Os resultados indicam que um aumento no metabolismo oxidativo estaria envolvido nesta resistência. Em um outro experimento, observou-se que uma acetilcolinesterase menos sensível a metidation estaria envolvida nesta resistência, sendo considerada porém, de importância secundária. Analisou-se também a penetração cuticular de metidation em $A$. womersleyi, verificando-se que a penetração não seria um fator envolvido nesta resistência. Estudou-se em seguida, o metabolismo "in vitro" do metidation, utilizando-se diferentes frações subcelulares destes ácaros. A degradação de $\left[{ }^{14} \mathrm{C}\right]$-metidation, pela fração microssomal dos ácaros resistentes, na presença de NADPH, foi 
$48 \%$ maior que a obtida para os ácaros suscetíveis, confirmando que as ofrn estariam envolvidas nesta resistência. Em um último experimento, comparou-se a toxicidade de oito pesticidas nas populações $\mathrm{R}$ e $\mathrm{S}$ do ácaro predador. A população $\mathrm{R}$ mostrou-se mais resistente que a população $\mathrm{S}$ a todos os inseticidas testados, com a exceção de bifenthrin. As maiores razões de resistência foram observadas para os inseticidas metidation, acefato e malation, para os quais a população $\mathrm{R}$ mostrou-se, respectivamente, 311; 20,4 e 13,1 vezes mais resistente que a população S. No caso do piretróide bifenthrin, nenhuma resistência cruzada foi observada para o produto. 


\title{
MECHANISMS OF RESISTANCE TO THE INSECTICIDE METHIDATHION IN Amblyseius womersleyi SCHICHA, 1975 (ACARI: PHYTOSEIIDAE)
}

\author{
Author: MÁRIO EIDI SATO \\ Adviser: Prof. Dr. OCTAVIO NAKANO
}

\section{SUMMARY}

The predaceous mite Amblyseius womersleyi Schicha is an important natural enemy of Kanzawa spider mite Tetranychus kanzawai Kishida, which is considered a key pest of tea in Japan. In order to study the mechanisms of methidathion in this phytoseiid mite, a resistant strain of $A$. womersleyi was selected for resistance; and along with this selection, a susceptible strain was selected for susceptibility to methidathion. After four selections for resistance and three selections for susceptibility, the resistance ratio $(\mathrm{R} / \mathrm{S})$ at the $\mathrm{LC}_{50}$ increased from 16 to 342 times. The effect of some synergists (PBO, DEM, and DEF) was investigated on the toxicity of methidathion in $A$. womersleyi. The highest synergistic ratio (SR: $\mathrm{LC}_{50}$ without synergist $/ C_{s_{0}}$ with synergist) was observed for piperonyl butoxide (inhibitor of mfo, mixed function oxidases), which increased 12.3 times the toxicity of the insecticide in the resistant population. A second test was carried out using PBO and PTPE (inhibitor of mfo) as synergists. The highest SR was observed for PTPE, with 59.3 times in the R strain. The results suggest that an increase in oxidative metabolism is involved in this resistance. In another experiment, an insensitive acetylcholinesterase was observed to have some effect on this resistance, however this acetylcholinesterase was thought to be a minor factor for resistance. Cuticular penetration of methidathion was also analyzed, and the results obtained indicate that the penetration is not a factor involved in this resistance. Another study was about "in vitro" metabolism of methidathion, using different subcellular fractions of the predaceous mite. The degradation of $\left[{ }^{14} \mathrm{C}\right]$-methidathion by the microsomal fraction of resistant mite, in the presence of NADPH, was $48 \%$ higher than that obtained for the susceptible strain, corroborating observations that mfo are involved in this resistance. In a final 
experiment, the toxicity of eight pesticides was evaluated in the $\mathrm{R}$ and $\mathrm{S}$ strains of this phytoseiid mite. The $\mathrm{R}$ strain showed to be more resistant to all compounds with the exception of bifenthrin. The highest resistance ratios were observed for the insecticides methidathion, acephate, and malathion, for which the R strain was respectively $311,20.4$, and 13.1 times more resistant than the $\mathrm{S}$ strain. In the case of the pyrethroid bifenthrin, no crossresistance was observed for this chemical. 


\section{INTRODUÇÃO}

A utilização de pesticidas em culturas comerciais tem sido a principal causa de desequilíbrio biológico e conseqüente ressurgência de pragas. Os tratamentos químicos são responsáveis pela redução populacional ou supressão de espécies benéficas, tais como os ácaros predadores da família Phytoseiidae (Vidal \& Kreiter, 1995). Os ácaros desta família são importantes inimigos naturais de ácaros fitófagos, pricipalmente da família Tetranychidae (Moraes, 1991).

Em um programa de manejo integrado de pragas (MIP), é preciso minimizar a resistência de pragas a pesticidas, assim como maximizar a resistência de inimigos naturais, permitindo assim a formação de um agroecossistema mais adaptado ao uso de pesticidas (Dunley et al., 1991).

O ácaro Amblyseius womersleyi Schicha, 1975 (Acari: Phytoseiidae) é um dos predadores promissores no controle de tetraniquídeos na Ásia, sendo encontrado em um grande número de plantas hospedeiras. Em chá, este fitoseídeo mostra-se como um dos principais inimigos naturais de Tetranychus kanzawai Kishida. que é praga chave da cultura. Nos últimos anos, tem sido observada no Japão a existência de populações desta espécie, resistentes a inseticidas organofosforados, como por exemplo metidation, em plantações comerciais de chá.

$\mathrm{O}$ inseticida metidation [0,0-dimetil-s-(2-metoxi-1,3,4-tiadiazol-5-(4 OH)-onil-4 metil)-ditio-fosfato] apresenta amplo espectro de ação, sendo eficiente para o controle de um elevado número de artrópodos pragas, em diversas culturas (Lakasa et al., 1990; James \& Omalley, 1992; Smith, 1995; Walker \& Aitken, 1996; Erkilik \& Uygun, 1997). 
Diversas informações já existem com relação à freqüência e distribuição de $A$. womersleyi resistente a metidation em campos de chá no Japão (Hamamura, 1987; Mochizuki, 1994); assim como sobre a genética desta resistência (Hamamura, 1987). Entretanto, não se dispõe até o momento de informações sobre os mecanismos envolvidos nesta resistência.

O estudo dos mecanismos de resistência é fundamental para se compreender a natureza da resistência a um pesticida em um determinado organismo e propor métodos mais adequados para o manejo desta resistência.

O presente trabalho teve como objetivo estudar os mecanismos de resistência ao inseticida organofosforado metidation em $A$. womersleyi, visando-se a utilização mais adequada das populações resistentes deste fitoseídeo em programas de manejo integrado de pragas. 


\section{REVISÃO DE LITERATURA}

\subsection{Amblyseius womersleyi Schicha (Acari: Phytoseiidae)}

A. womersleyi pertence à família Phytoseiidae. Os ácaros desta família pertencem à subordem Gamasida (Mesostigmata para alguns autores) e superfamília Phytoseioidea. Os ácaros fitoseídeos são normalmente pouco menores que os ácaros da família Tetranychidae. Os fitoseídeos normalmente movem-se mais rapidamente que suas presas; e apresentam um aspecto brilhante quando vivos (Chant, 1985).

A espécie $A$. womersleyi foi descrita por Schicha (1975) a partir de exemplares coletados de morango na Austália. Os ácaros desta espécie apresentam normalmente uma coloração amarelada, sendo que, os adultos fềmeas possuem aproximadamente $350 \mu \mathrm{m}$ de comprimento.

A. womersleyi apresenta ampla distribuição geográfica, ocorrendo em países como Rússia. China, Coréia, Japão, Taiwan, Filipinas, Austrália e Nova Zelândia; sobre diversas plantas, tais como chá, pêssego, morango, mamão, uva, milho, bambu, amendoim, feijão, plantas daninhas, ornamentais, etc. (Ho et al., 1995). Estes autores apresentaram uma lista de 42 espécies botânicas sobre as quais este ácaro predador é encontrado.

\subsubsection{Aspectos biológicos e ecológicos}

A biologia de $A$. womersleyi foi estudada por Kim et al. (1996a), a $25^{\circ} \mathrm{C}$, fotofase de 16 h e umidade relativa de 70 a $80 \%$, utilizando ovos de $T$. kanzawai como alimento. $\mathrm{O}$ período médio de desenvolvimento de ovo a adulto foi de 4,8 dias e o período médio de 
cada geração de 8,6 dias. O número de ovos por fềmea foi de 34,2. A taxa intrínseca de crescimento foi estimada em 0,349 .

Ho et al. (1995) observaram que o consumo total de ovos de T. kanzawai, durante os estágios de larva, protoninfa e deutoninfa de $A$. womersleyi, foi de 15,3 (fềmeas) e 11,5 (machos).

Segundo Kim et al. (1996a), cada fềmea grávida deste predador consumiu 3,0; 4,9; 15,7; e 19,4 ovos de T. kanzawai por dia a $15,20,25$ e $30^{\circ} \mathrm{C}$, respectivamente. O consumo médio foi de 4,6;6,3;6,8 ovos por dia por protoninfa, deutoninfa e fềmea durante a préoviposição; e 19,4 ovos por dia, durante a oviposição, para a temperatura de $30^{\circ} \mathrm{C}$.

Kim et al. (1996b) observaram que larvas e ninfas deste ácaro predador apresentaram pouco movimento entre folhas, em plantas de chá, moderadamente infestadas por T. kanzawai. Adultos movimentaram-se mais que outros estágios de desenvolvimento. Todos os estágios de $A$. womersleyi movimentaram-se bem menos em plantas altamente infestadas por T. kanzawai que em plantas pouco infestadas. A liberação de 200 a 400 ácaros $A$. womersleyi em uma área de $100 \mathrm{~m}^{2}$ de chá conseguiu suprimir a população de $T$. kanzawai, em um período de três semanas. Nesta área, a população inicial de $T$. kanzawai era inferior a 360 ácaros/100 folhas.

A liberação massal de aproximadamente 100.000 ácaros predadores desta espécie por hectare, causou reduções significativas na população de ácaros tetraniquídeos em plantações de amora, em Taiwan (Shih, 1985).

Segundo Waite (1988), A. womersleyi é freqüentemente encontrado na cultura do morango na Austrália, sendo capaz de controlar ácaros tetraniquídeos se os predadores desta espécie colonizarem as plantas logo após o início da infestação dos ácaros pragas, e desde que, nenhum inseticida muito tóxico ao fitoseídeo seja aplicado.

Uma colonização natural por $A$. womersleyi controlou a população de $T$ : urticae em duas culturas comerciais de morango em Queensland. Embora infestações significativas de ácaro rajado tenham sido observadas durante várias semanas, estas infestações se limitaram às partes mais baixas das plantas, não causando prejuízos significativos no vigor ou na produção destas plantas (Waite, 1988). 


\subsection{Resistência de inimigos natu rais a pesticidas}

Agentes de controle de biológico são normalmente mais sensíveis aos pesticidas do que as pragas alvos (Croft \& Brown, 1975; Croft \& Strickler, 1983; Hoy, 1990). Duas hipóteses genéricas têm sido apresentadas para explicar a taxa aparente menor de resistência a pesticidas em parasitóides ou predadores, em relação aos insetos pragas, presentes nos ecossistemas agrícolas. Estas hipóteses seriam as da preadaptação diferencial e a da limitação de alimento (Croft \& Morse, 1979; Tabashnik, 1986). A hipótese da preadaptação diferencial menciona que os insetos pragas podem desenvolver a resistência mais rapidamente que os inimigos naturais devido às seguintes razões: 1) apresentam melhor capacidade intrínseca de desintoxicação; 2) têm maior tolerância intrínseca aos pesticidas; 3 ) possuem maior variação genética na tolerância aos pesticidas; 4) os custos de adaptação associados à resistência é menor em espécies pragas, comparadas com os inimigos naturais (Baker \& Arbogast, 1995). Um princípio da hipótese da limitação de alimento é que o desenvolvimento da resistência em espécies fitófagas (presas) deve preceder ao desenvolvimento da resistência nos predadores associados (Croft \& Morse, 1979). Somente com o aparecimento da resistência em espécies presas, a fonte de alimento deixa de ser um fator limitante, permitindo ao inimigo natural a possibilidade de desenvolvimento de populações resistentes (Baker \& Arbogast, 1995).

Os herbívoros podem ser melhor adaptados a degradar os pesticidas por estarem comumente expostos aos compostos secundários (aleloquímicos) das plantas. Muitas evidências indicam que os aleloquímicos são produzidos pelas plantas para deter os herbívoros. Em resposta, os herbívoros podem aumentar as atividades das enzimas de desintoxicação, permitindo-lhes que se alimentem de plantas sem sofrer o efeito destes compostos (Mullin et al., 1982).

\subsection{Resistência de ácaros da família Phytoseiidae a pesticidas}

Estudos envolvendo aspectos biológicos e ecológicos têm indicado que os ácaros desta família são os principais agentes de controle biológico de ácaros tetraniquídeos em 
casas de vegetação, fruteiras decíduas, videiras e citros (Hoy, 1985). Atualmente são conhecidas mais de mil espécies de fitoseídeos em todo o mundo (Moraes et al., 1986; Moraes, 1991; Moraes, 1992).

Após o aparecimento de resistência a pesticidas em ácaros tetraniquídeos, também se observou o mesmo em seus inimigos naturais, principalmente em ácaros da família Phytoseiidae. Embora a resistência a inseticidas não seja freqüente em inimigos naturais, atualmente são conhecidos diversos casos de resistência em ácaros predadores desta família (Hoy, 1990). Os ácaros fitoseídeos apresentam taxas reprodutivas elevadas, pseudoarrenotoquia, exibem características de migração e atributos de colonização que favorecem a evolução da resistência a pesticidas, em uma escala microgeográfica (Croft \& Van de Baan, 1988). Além disso, os fitoseídeos são abundantes em quase todo o mundo; apresentam um ciclo biológico curto, onde na maioria das espécies o período de desenvolvimento de ovo a adulto é de aproximadamente uma semana (Hoy, 1985). A resistência a pesticidas tem sido documentada em populações nativas de fitoseídeos, principalmente das espécies Amblyseius fallacis (Garman), Metaseiulus occidentalis (Nesbitt), Phytoseiulus persimilis Athias-Henriot e Typhlodromus pyri Scheuten (Hoy et al., 1979; Roush \& Hoy, 1981; Strickler \& Croft, 1982; Croft \& Strickler, 1983; Hoy, 1985).

A utilização de fitoseídeos resistentes a pesticidas em programas de controle integrado, durante as últimas décadas, tem contribuído para o aprimoramento do manejo de pragas a nível mundial e redução do número de casos de resistência em tetraniquídeos (FAO, 1984).

Programas de manejo integrado têm se utilizado tanto de populações de fitoseídeos resistentes evoluídas no campo ou conseguidas em laboratório (Hoy \& Knop, 1981; Hoy, 1985; Fournier et al., 1987b; Hoy \& Ouyang, 1989; Hoy, 1990). O uso destes inimigos naturais resistentes é parte integrante do manejo de ácaros tetraniquídeos em diversas culturas, incluindo pêssegos (Field, 1978), amêndoas (Hoy, 1985) e plantas de casas de vegetação (Hussey \& Scopes, 1985).

A introdução de fitoseídeos para novas regiões geográficas cuja resistência foi desenvolvida em campo, tem freqüentemente resultado em um controle biológico efetivo 
(Croft \& Barnes, 1972; Field, 1978; Penman et al., 1979), sendo uma forma análoga ao controle biológico clássico, porém utilizando um biótipo diferenciado de inimigo natural (Dunley et al., 1991).

Segundo Blommers (1994), o aparecimento de populações de T. pyri resistentes a vários inseticidas organofosforados e carbamatos, utilizados no controle de insetos pragas, favoreceu muito o uso prático destes predadores em programas de manejo integrado de pragas, em pomares de maçã, na Europa. T. pyri realiza um excelente controle do ácaro tetraniquídeo Panonychus ulmi (Koch) e também, freqüentemente do eriofídeo Aculus schelechtendali (Nalepa). Uma liberação de ácaros T. pyri resistentes a organofosforados é o primeiro passo em um programa de manejo de pragas. Na Holanda, brotos de plantas de maçã colonizadas por T. pyri são coletados em pomares onde se realiza o manejo integrado de pragas (MIP), normalmente durante a poda de verão, e transferidos imediatamente para novas plantações. Neste caso, um ou dois brotos são colocados por planta, em todas as árvores, pois T. pyri apresenta uma taxa de dispersão relativamente lenta (Gruys, 1982; Blommers, 1994). Em condições de clima temperado, T. pyri usualmente torna-se numeroso o suficiente para controlar adequadamente $P$. ulmi em um período de um ano; porém, em certas variedades, são necessários três anos para que a população do predador se torne estável. Este sistema de MIP, utilizando ácaros predadores resistentes a inseticidas organofosforados, tem sido adotado por plantadores de maçã, da Alemanha, Áustria, Holanda, norte da Itália, Polônia, Reino Unido e Suíça (Blommers, 1994).

Foram observados recentemente no Japão populações de $A$. womersleyi resistentes a inseticidas organofosforados, carbamatos e piretróides na cultura do chá (Hamamura, 1987; Mochizuki, 1992; Mochizuki, 1994; Kawai, 1997). Estes ácaros têm apresentado razões de resistência superiores a 100 vezes para alguns inseticidas como o organofosforado metidation e o carbamato metomil (Kawai, 1997). O aparecimento de populações de $A$. womersleyi resistentes a inseticidas tem favorecido signicativamente o controle biológico de T. kanzawai, em campos comerciais da cultura naquele país (Kawai, 1997).

Hamamura (1987) realizou estudos genéticos sobre a resistência de $A$. womersleyi a metidation e concluiu que esta resistência era devida a um gene principal completamente dominante, sendo o grau de dominância de 0,899 . 
Segundo Mochizuki (1997), a resistência a metidation neste fitoseídeo mostrou-se relativamente estável em condições de laboratório, ocorrendo apenas um ligeiro declínio do nível de resistência ao longo de 20 meses.

\subsection{Mecanismos de resistência}

Entre os principais mecanismos pelos quais os artrópodos podem adquirir resistência a pesticidas estão: redução da penetração cuticular (Noppun et al., 1989; Fergusson-Kolmes et al., 1991), alteração do alvo de ação (Voss, 1980; Hama, 1983; Carbonaro et al., 1986; Tag Eldin, 1990; Bourguet et al., 1996; Yu \& Nguyen, 1996; Guedes \& Dover, 1997) e aumento da desintoxicação (Oppenoorth, 1985), podendo-se citar o envolvimento de algumas enzimas como hidrolases (esterases, fosfatases) (Miyata \& Saito, 1976; Devonshire, 1977; Kuwahara et al., 1982; Miyata, 1983; Andrade \& Branco Jr., 1990; Sakata \& Miyata, 1994), oxidases (principalmente dependente das monooxigenases do citocromo P-450) (Kasai et al., 1998), e transferases. Entre as do último grupo, as transferases de glutatiom são as únicas envolvidas na resistência, entre várias outras transferases que podem estar relacionadas ao metabolismo de compostos estranhos, como os inseticidas (Fournier et al., 1987a).

A redução na penetração foi observada em muitos artrópodos resistentes, porém. em comparação com os outros tipos de resistência, a penetração reduzida é de importância secundária. Este tipo de resistência torna-se mais importante quando associado com um outro mecanismo de resistência, como o aumento da desintoxicação (Oppenoorth, 1984: Campanhola, 1990). Hirai et al. (1973) observaram penetração de 62 a $64 \%$ da dose de ${ }^{32} \mathrm{P}-$ dimetoato aplicada em uma população suscetível de Panonychus citri McGregor, mas somente $15 \%$ da dose aplicada em uma população resistente. Esta penetração cuticular reduzida foi considerada como um fator envolvido na resistência deste tetraniquídeo ao inseticida testado. Um exemplo de alteração no alvo de ação envolve a redução da sensibilidade de acetilcolinesterase, que corresponde ao local de ação de inseticidas organofosforados e carbamatos (Campanhola, 1990). Este mecanismo foi observado pela 
primeira vez em ácaro rajado, $T$. urticae, que mostrou-se menos sensível a organofosforados (Smissaert, 1964).

O mecanismo de resistência baseado no aumento da capacidade de degradar produtos tóxicos é provavelmente o mais comum em artrópodos. Este mecanismo é importante para inseticidas biodegradáveis como os organofosforados e carbamatos (Plapp \& Wang, 1983; Plapp, 1986). O aumento na atividade de oxidases com funções múltiplas é um dos mecanismos mais freqüentes de resistência a inseticidas. Acredita-se que estas enzimas microssomáticas evoluíram como um mecanismo de proteção contra substâncias tóxicas de ocorrência natural nas plantas. Uma das características das oxidases com funções múltiplas é sua baixa especificidade de substrato, o que resulta em padrões de resistência não restritos a grupos específicos de inseticidas (Wilkinson, 1983; Campanhola, 1990).

Os sistemas de desintoxicação parecem ter uma grande flexibilidade, e muitos insetos são capazes de adquirir adaptações genéticas para um elevado número de inseticidas, quando sob pressão de seleção contínua. Os vários mecanismos podem agir sozinhos ou em combinação, e em espécies que se adaptam muito facilmente, ocorrem biótipos que podem resistir a muitos inseticidas (Oppenoorth, 1985).

No caso de ácaros da família Phytoseiidae, Motoyama et al. (1971) reportaram um mecanismo de resistência envolvendo S-transferases de glutatiom, em uma população de A. fallacis (Garman) resistente a azinfós-metílico. Foi observada na população resistente um aumento de três vezes na atividade destas transferases. Considerando-se que as transferases de glutatiom são específicas para substratos com radical metil, estes dados sugeriram que estes ácaros poderiam ser menos resistentes a compostos organofosforados contendo ésteres etílicos do que a compostos contendo ésteres metílicos. Motoyama et al. (1977) compararam as toxicidades de compostos análogos de azinfós-metílico, para as populações suscetível e resistente de $A$. fallacis, verificando que a resistência decrescia para os análogos etil e $n$-propil, confirmando serem as transferases de glutatiom as responsáveis pela resistência.

Roush \& Plapp (1982) observaram um aumento na desintoxicação oxidativa em uma população de $M$. occidentalis resistente a carbaril e propoxur. Um aumento nas atividades de esterases foi mencionado para A. fallacis (Mullin et al., 1982). Uma redução 
na sensibilidade de acetilcolinesterase foi verificada em populações de T. pyri (Van de Baan et al., 1985) e de Amblyseius potentillae (Garman) resistentes a organofosforados (Anber \& Overmeer, 1988). Além disso, Anber \& Oppenoorth (1989) mencionaram a presença de uma ali-esterase mutante para explicar a resistência de uma população de $A$. potentillae a inseticidas deste grupo químico. Assim sendo, a resistência de fitoseídeos a compostos organofosforados pode resultar de vários mecanismos enzimáticos, de acordo com as espécies ou os inseticidas envolvidos (Fournier et al., 1987a). 


\section{MATERIAL E MÉTODOS}

Os experimentos foram conduzidos no Laboratório de Entomologia Aplicada da Escola de Ciências Agrícolas/Universidade de Nagoya, em Nagoya, Província de Aichi, Japão, no período de abril de 1997 a novembro de 1998.

\subsection{Populações de ácaros}

A criação de ácaros predadores foi iniciada a partir de populações de ácaros fornecidas em 28/04/97, pelo Departamento de Agronomia do Chá/Instituto Nacional de Pesquisa de Vegetais, Plantas Ornamentais e Chá, localizado em Kanaya, Shizuoka, Japão. Foram fornecidas duas populações de $A$. womersleyi: uma resistente a inseticidas e outra suscetível.

A população resistente, originária de plantas de chá Camelia sinensis (L.) Ktze., em Kanaya, Shizuoka, em 31/05/94, apresentava resistência principalmente a inseticidas organofosforados (Mochizuki, 1996). A população suscetível, originária de plantas de feijão Phaseolus vulgaris L., em Ishigaki, Okinawa, Japão, em 12/12/93, mostrava-se suscetível a diversos grupos de inseticidas (Mochizuchi, 1996).

Após a coleta, ambas as populações foram mantidas em laboratório, até o início dos experimentos do presente trabalho em maio de 1997. Durante este periodo, os ácaros suscetíveis foram mantidos livres de qualquer tratamento químico. 


\subsection{Criação de ácaros}

\subsubsection{Criação de ácaros presas}

O ácaro rajado, $T$. urticae, foi utilizado como fonte de alimento, para a criação de $A$. womersleyi. T. urticae foi criado em plantas de $P$. vulgaris, cultivadas em vasos de cerâmica com capacidade de aproximadamente $450 \mathrm{~cm}^{3}$.

No plantio, foram colocadas dez sementes de feijão por vaso. Utilizou-se apenas vermiculita como substrato para as plantas. Após o plantio, adicionava-se aproximadamente 1,0 g de fertilizante (NPK: 8 - 8 - 8) em cada vaso. Os vasos eram colocados no interior de uma bandeja plástica branca de $44 \times 32,5 \times 7,5 \mathrm{~cm}$. Foi mantido um nível de $3 \mathrm{~cm}$ de água no interior das bandejas, para o fornecimento de água para as plantas. Os vasos foram mantidos em câmaras climatizadas a $25 \pm 1^{\circ} \mathrm{C}$, umidade relativa de $70 \pm 5 \%$ e fotofase de $16 \mathrm{~h}$.

\subsubsection{Criação de ácaros predadores}

A. womersleyi foi criado em plantas de feijão, infestadas com $T$. urticae. As plantas infestadas pelo ácaro rajado foram cortadas logo acima da superficie do solo e transferidas para uma bandeja de alumínio $(27,5 \times 20,9 \times 3,5 \mathrm{~cm})$. As plantas eram mantidas sobre duas camadas de espuma plástica azul $(16,5 \times 11 \times 1 \mathrm{~cm})$, colocadas sobrepostas, na parte central da bandeja. A espuma colocada na parte superior era envolta por um saco plástico transparente, e servia como substrato para as plantas. Adicionava-se água no interior desta bandeja, até cobrir a espuma inferior, visando-se o fornecimento de água para as plantas, que eram mantidas com a extremidade inferior do caule (região do corte) mergulhado na água. Esta água também servia como barreira para evitar a fuga dos ácaros predadores. Abaixo desta bandeja era colocada uma outra bandeja $(31 \times 23,9 \times 3,5 \mathrm{~cm})$, na qual era colocada água com detergente para evitar a entrada de organismos externos na criação. Entre as duas bandejas (superior e inferior) eram colocados quatro copos plásticos (60 $\mathrm{cm}^{3}$ ), que serviam de suporte para a bandeja superior. 
As bandejas foram mantidas em câmaras climatizadas a $25 \pm 1^{\circ} \mathrm{C}$, umidade relativa de $70 \pm 5 \%$ e fotofase de 16 horas. As populações resistente e suscetível de $A$. womersleyi foram criadas em locais isolados.

\subsection{Testes toxicológicos}

Um lote de 20 fêmeas adultas de $A$. womersleyi foi colocado sobre a superfície de um disco de folha de feijão ( $4 \mathrm{~cm}$ de diâmetro), colocada sobre uma camada de algodão hidrófilo, em uma placa de Petri (9 $\mathrm{cm}$ de diâmetro). A camada de algodão foi mantida sempre saturada com água destilada. Foi colocada também, uma camada de algodão úmido acompanhando a margem externa da folha, formando uma barreira para evitar a fuga dos ácaros predadores.

Os testes toxicológicos foram realizados utilizando-se a metodologia descrita por Mochizuki (1994). Aplicou-se uma suspensão do inseticida organofosforado metidation (Supracid 40\% CE) sobre os ácaros, em torre de pulverização ("Rotatory Spray Tower", fabricado pela "Mizuho Scientific Co., Ltd."), utilizando-se 7,5 ml de calda e uma pressão de $213 \mathrm{hPa}$. Testes preliminares indicaram que 4 a $5 \mathrm{mg}$ de água destilada foram pulverizados por $\mathrm{cm}^{2}$, sobre o disco de folha, para este volume e pressão. A mortalidade foi avaliada 48 horas após o tratamento. Foram considerados mortos os ácaros que não se moviam, ao serem tocados levemente com pincel de pêlo macio. Os ácaros encontrados na água ou presos na barreira de algodão não foram considerados na avaliação de mortalidade.

Para obtenção das curvas de regressão concentração-mortalidade, foram utilizadas de 5 a 7 concentrações de metidation. Cada teste foi repetido pelo menos 3 vezes. Os resultados foram submetidos à análise de Probit (Finney, 1971). O programa utilizado para esta análise foi desenvolvido no Departamento de Agricultura, da Universidade de Nagoya.

Todos os bioensaios desta pesquisa foram conduzidos a $25 \pm 1^{\circ} \mathrm{C}$, umidade relativa de $70 \pm 5 \%$ e fotofase de $16 \mathrm{~h}$. 


\subsection{Seleção artificial}

Foram realizadas seleções artificiais visando o aumento da resistência a metidation na população resistente $(\mathrm{R})$, assim como, o aumento da suscetibilidade ao produto, na população suscetível(S) de $A$. womersleyi.

\subsubsection{Seleção artificial para resistência}

Esta seleção foi realizada em laboratório, utilizando-se a população mais resistente a metidation. A aplicação foi realizada com torre de pulverização ("Rotatory Spray Tower"), diretamente sobre os ácaros colocados em arenas de folha de feijão, como descrito anteriormente. Foram colocadas em média 50 fêmeas adultas de $A$. womersleyi por arena, sendo realizadas 4 seleções utilizando-se concentrações crescentes do inseticida a cada ciclo de seleção, procurando-se obter mortalidades entre 50 a 70\%. Foram utilizados pelo menos 850 ácaros em cada seleção. O intervalo entre uma seleção e outra foi de 24 a 28 dias, o que correspondeu ao período de aproximadamente 3 gerações (Kim et al., 1996a).

Os sobreviventes após $24 \mathrm{~h}$ do tratamento foram utilizados para a formação de novas colônias. A criação destes ácaros foi conduzida como descrita anteriormente.

\subsubsection{Seleção artificial para suscetibilidade}

A seleção para suscetibilidade foi baseada na metodologia descrita por Fournier et al. (1988). Fêmeas grávidas de A. womersleyi foram isoladas em arenas constituídas de círculos de folha de feijão (2,5 cm de diâmetro) colocada sobre uma camada de algodão úmido, no interior de um copo plástico de $60 \mathrm{~cm}^{3}$. Uma camada adicional de algodão úmido foi colocada ao redor da margem da folha, como barreira para evitar a fuga do ácaro. Juntamente com o ácaro predador foram colocados, como alimento, diferentes estágios de desenvolvimento de $T$. urticae. 
Após a colocação do predador, o copo plástico foi fechado com tampa, para evitar qualquer possibilidade de migração do predador, de uma arena a outra. As fềmeas foram mantidas nesta arena, por um período de $48 \mathrm{~h}$, período em que houve a oviposição média de 4,2 ovos por fềmea. Após este período, a fềmea do ácaro predador foi transferida para outra arena (semelhante à anterior), onde sofreu um tratamento químico, através da aplicação de uma suspensão de metidation em torre de pulverização. Os ovos e as formas jovens das fềmeas que morreram, após o tratamento, foram utilizados para a formação das novas colônias.

Foram realizadas três seleções para suscetibilidade, utilizando-se concentrações decrescentes de metidation, para cada ciclo de seleção, que causaram mortalidades entre 32 e $41 \%$, nas fềmeas de $A$. womersleyi. O intervalo entre as seleções variou de 31 a 35 dias.

\subsection{Testes toxicológicos com tubo de vidro e arena de folha}

Nestes testes, foram utilizadas fềmeas de $A$. womersleyi da populações $\mathrm{R} \mathrm{e} \mathrm{S}$, para se comparar as taxas de resistência a metidation, colocando-se os ácaros em arena de folha ou em tubo de vidro. Este teste foi realizado também, para se verificar a possibilidade do uso de tubo de vidro nos testes com sinergistas.

Estes testes com tubo de vidro e arena de folha, assim como o teste 1 com sinergistas, foram realizados durante $\mathrm{o}$ processo de seleção para resistência $\mathrm{e}$ suscetibilidade a metidation. Neste caso a população resistente foi a selecionada com o inseticida a 400 ppm e a população suscetível foi a selecionada com 4 ppm.

Todos os outros experimentos foram realizados após o término da seleção, com a população resistente selecionada com metidation a 500 ppm e a suscetível selecionada com 2 ppm.

\subsubsection{Teste com tubo de vidro}

Foram colocados $200 \mu 1$ de solução acetônica de metidation ("padrão", 96,18\% de pureza) em cada tubo de vidro de $10 \mathrm{~cm}$ de comprimento $\mathrm{x} 1,2 \mathrm{~cm}$ de diâmetro, 
espalhando-se a solução em toda superfície interna do tubo. No caso da testemunha, apenas acetona (padrão analítico) foi colocada nos tubos. Após a secagem, aproximadamente 20 fềmeas adultas foram colocadas no interior de cada tubo, fechando-se o mesmo em seguida com parafilme. A avaliação da mortalidade foi realizada 24 horas após a colocação dos ácaros nos tubos. Seis concentrações do inseticida foram utilizadas, tanto para a população suscetível como para a resistente, para a obtenção das curvas de regressão concentraçãomortalidade e $\mathrm{CL}_{50}$ para metidation.

\subsubsection{Teste com arena de folha}

Vinte fềmeas adultas de $A$. womersleyi foram colocadas em arenas de folha de feijão semelhantes às descritas anteriormente (Testes toxicológicos). Foram utilizadas 5 concentrações do inseticida, para a obtenção das curvas de regressão concentraçãomortalidade para a população resistente e 6 para a população suscetível.

Ambos os testes foram repetidos 4 vezes, realizando-se posteriormente a análise de Probit.

\subsection{Testes toxicológicos utilizando sinergistas}

\subsubsection{Teste 1 com sinergistas}

Os produtos sinergistas utilizados nos experimentos foram:

- PBO (butóxido de piperonila), produzido pela empresa Tokyo Kasei, Tóquio, Japão.

- DEM (dietil maleato), produzido pela mesma empresa.

- DEF (S,S,S - tributilfosforotritioato), adquirido da empresa Chem Service, West Chester. PA, USA.

PBO é um conhecido inibidor de ofm (oxidases com funções múltiplas); DEM é inibidor de S-transferases de glutatiom (STG) e ofm; e DEF é inibidor de esterases e STG (Fournier et al., 1987a). 
Todos os produtos químicos utilizados foram do mais alto grau de pureza comercialmente disponível (acima de 95\%).

\subsubsection{Estimativa da "concentração subletal máxima" para sinergistas}

Esta concentração foi obtida utilizando-se a população suscetível de $A$. womersleyi. Em um tubo de vidro de $10 \mathrm{~cm}$ x 1,2 cm de diâmetro, foram colocados e distribuídos 200 $\mu \mathrm{l}$ de solução acetônica de um dos sinergistas. O número de concentrações utilizadas de cada sinergista foi respectivamente de 6,6 e 7, para PBO, DEM e DEF. Após a secagem, foram transferidas 20 fềmeas adultas de $A$. womersleyi por tubo, fechando-o em seguida com parafilme. A avaliação da mortalidade foi realizada após a exposição dos ácaros aos sinergistas por um período de $24 \mathrm{~h}$. Todos os testes com sinergistas foram repetidos 4 vezes, submetendo os resultados à análise de Probit.

\subsubsection{Bioensaio}

Os testes foram baseados na metodologia adotada por Foumier et al. (1987a), com modificações, como descrito a seguir. Foram colocados $200 \mu \mathrm{l}$ de solução acetônica de um dos sinergistas em um tubo de vidro de $10 \mathrm{~cm}$ de comprimento $\times 1,2 \mathrm{~cm}$ de diâmetro, ditribuindo-se a solução por toda superfície interna do tubo e deixando secar. As concentrações dos sinergistas PBO, DEM e DEF utilizadas no experimento, tanto para a população suscetível como para a resistente, foram respectivamente de 105,6; 26,8 e 2,0 $\mu \mathrm{V} / 100 \mathrm{ml}$ de acetona. Estas concentrações foram determinadas com base nos resultados do experimento anterior (3.6.1.1.). Posteriormente, aproximadamente 20 fềmeas adultas de $A$. womersleyi foram introduzidas no interior de cada tubo. Após a colocação dos predadores, o tubo foi fechado com parafilme, para impedir a fuga dos mesmos. Os ácaros foram deixados no interior do tubo, em contato com o sinergista, por um período de 4 h. Após este período, os ácaros foram transferidos para um outro tubo, previamente tratado com $200 \mu \mathrm{l}$ de solução acetônica de metidation ("padrão", com 96,18\% de pureza) e deixado a secar. Em seguida, este segundo tubo foi fechado com parafilme. A mortalidade foi avaliada após 
24 h. No caso da testemunha, os ácaros foram tratados com o sinergista e em seguida transferidos para tubos previamente tratados apenas com acetona (padrão analítico).

Foram obtidas as curvas de regressão concentração-mortalidade e as $\mathrm{CL}_{50}$, para metidation, realizando-se o tratamento de $A$. womersleyi das populações $\mathrm{R}$ e $\mathrm{S}$, utilizandose 6 a 8 concentrações do inseticida organofosforado.

\subsubsection{Teste 2 com sinergistas}

Este teste foi realizado com algumas modificações em relação ao teste 1, com o intuito de se avaliar melhor o efeito de sinergistas inibidores de oxidases com funções múltiplas, na toxicidade de metidation em $A$. womersleyi.

Os sinergistas utilizados foram:

- PBO (butóxido de piperonila)

- PTPE (2-propinil 2,3,6-triclorofenil eter) produzido pela Nihon Bayer Agrochem K.K., Japão.

O PTPE é um outro inibidor de monooxigenases de P-450 (KASAI et al., 1998)

\subsubsection{Estimativa da "concentração subletal máxima" para sinergistas}

Neste experimento, a concentração subletal máxima foi obtida utilizando-se as populações $\mathrm{S}$ (selecionada para suscetibilidade, com 2 ppm de metidation) e $\mathrm{R}$ (selecionada para resistência, com 500 ppm de metidation) do ácaro predador. Em um tubo de vidro de $10 \mathrm{~cm} \times 1,3 \mathrm{~cm}$ de diâmetro, com tampa de vidro, foram colocados e distribuídos $200 \mu \mathrm{lde}$ solução de um dos sinergistas. A parte interna da tampa de vidro também foi tratada com sinergista. Após a secagem do tubo, foram colocados aproximadamente 20 fêmeas adultas em cada tubo, fechando-o em seguida. Os ácaros foram mantidos no interior do tubo por 4 h. Após este período, os ácaros foram tranferidos para outro tubo, não tratado. Este segundo 
tubo foi fechado com parafilme. A avaliação da mortalidade foi realizada $24 \mathrm{~h}$ após a transferência.

\subsubsection{Bioensaio}

O experimento foi realizado seguindo a mesma metodologia descrita para o Bioensaio (Teste 1), colocando-se porém, os ácaros em contato com os sinergistas (por $4 \mathrm{~h}$ ) no interior de tubos de $10 \mathrm{~cm} \times 1,3 \mathrm{~cm}$ de diâmetro, fechados com tampa de vidro, tratada com sinergista.

As concentrações dos sinergistas PBO e PTPE utilizadas no experimento, para a população suscetível, foram respectivamente de 1,06 e $0,016 \mathrm{mg} / \mathrm{ml}$ de acetona. No caso da população resistente, foram utilizadas 2 concentrações de cada sinergista. As concentrações de PBO foram de 1,06 e 2,11 mg/ml; e de PTPE foram de 0,016 e 0,062 mg/ml. Estas concentrações foram determinadas com base nos resultados do experimento anterior.

\subsection{Alteração no alvo de ação}

Neste experimento foram analisadas as acetilcolinesterases das populações resistente e suscetível de $A$. womersleyi.

As populações $\mathrm{S}$ e $\mathrm{R}$ utilizadas neste estudo foram aquelas selecionadas, respectivamente, para suscetibilidade e resistência a metidation. A razão de resistência $(\mathrm{R} / \mathrm{S})$ ao nível de $\mathrm{CL}_{50}$ era de 342 vezes.

O inibidor utilizado foi metidation oxon (99,9\% de pureza), produzido pela NOVARTIS/Japão. Todos os reagentes utilizados neste estudo foram de padrão analítico.

\subsubsection{Preparo da enzima}

Neste estudo, 100 fềmeas adultas de cada população ( $\mathrm{S}$ ou R) foram colocadas em um tubo de polipropileno (tubo Eppendorf - $0,5 \mathrm{ml}$ ) contendo $250 \mu \mathrm{l}$ de solução tampão $\left(0,1 \mathrm{M}\right.$ MOPS $\left.-\mathrm{C}_{7} \mathrm{H}_{15} \mathrm{NO}_{4} \mathrm{~S}-\mathrm{pH} 7,5\right)$. Os ácaros foram homogeneizados, através de um 
homogeneizador ultra-sônico (Ultra Disruptor UV-200 - Tomy Co.), utilizando o nível de força 1, por 1 a $2 \mathrm{~s}$ por duas vezes, no interior dos tubos, mantidos resfriados em gelo. $\mathrm{O}$ sobrenadante resultante da centrifugação a $13.000 \mathrm{~g}$ por $2 \min \left(4^{\circ} \mathrm{C}\right)$ foi utilizado como fonte de enzima.

\subsubsection{Determinação da concen tração de proteína}

A concentração de proteína foi determinada de acordo com o método de Bradford (1976), utilizando-se albumina de soro de bovino como padrão (kit para avaliação de proteína: Japan Bio-Rad, Japão).

Após a determinação da concentração de proteína nos homogeneizados, realizou-se a diluição dos mesmos com solução tampão, para se obter uma concentração de proteína equivalente a $0,5 \mathrm{mg} / \mathrm{ml}$ para os sobrenadantes referentes às populações suscetível e resistente do ácaro.

\subsubsection{Atividade de acetilcolinesterase}

A atividade de acetilcolinesterase (ACoE) foi avaliada baseando-se no método colorimétrico de Ellman et al. (1961), utilizando acetiltiocolina como substrato. Foram comparadas as atividades de $\mathrm{ACoE}$ das duas populações de ácaros ( $\mathrm{S}$ e R).

Neste teste, $20 \mu \mathrm{l}$ do homogeneizado foram colocados em cada poço da placa de 96 poços. Em seguida, foram adicionados em cada poço $200 \mu \mathrm{l}$ de uma mistura contendo solução tampão (0,1 M MOPS, pH 7,5); $0,4 \times 10^{-3} M$ DTNB (ácido 5,5'-ditiobis-2nitrobenzóico); $0,7 \times 10^{-3} \mathrm{MNaHCO}_{3}$ (bicarbonato de sódio); e iodeto de acetiltiocolina em diferentes concentrações, indicadas a seguir: 1) $6,1 \times 10^{-7} \mathrm{M}$; 2) $2,44 \times 10^{-6} \mathrm{M}$; 3) $9,77 \mathrm{x}$ $10^{-6} \mathrm{M}$; 4) $3.91 \times 10^{-5} \mathrm{M}$; 5) $1,56 \times 10^{-4} \mathrm{M}$; 6) $6,25 \times 10^{-4} \mathrm{M}$; 7) $2,5 \times 10^{-3} \mathrm{M}$; 8) $1,0 \times$ $10^{-2} M$. Para cada concentração do substrato, foram realizadas 7 repetições.

A atividade de $\mathrm{ACoE}$ foi monitorada através de um leitor de micro placa (Micro Plate Reader. modelo 450 - Bio Rad Co., Japão) utilizando um filtro de $405 \mathrm{~nm}$. As leituras 
foram realizadas aos $0,30,60$ e 90 minutos. $\mathrm{O}$ experimento foi realizado a $25^{\circ} \mathrm{C}$, sendo que, entre as leituras, a placa de 96 poços foi mantida em "banho-maria" $\left(25^{\circ} \mathrm{C}\right)$.

Os valores de $K \mathrm{~m}$ (constante de Michaelis) e $V \max$ (velocidade máxima) foram calculados de acordo com Hart \& O’Brien (1973). Vmax é a velocidade máxima para uma reação enzima-substrato, na ausência de inibidor, ocorrendo em altas concentrações do substrato, quando a enzima está saturada. $K \mathrm{~m}$ é a concentração do substrato para a qual a velocidade da reação é a metade da máxima $(V \max / 2)$.

\subsubsection{Teste de inibição}

Os valores de $\mathrm{I}_{50}$ (taxa de inibição $50 \%$ ) de $\mathrm{ACoE}$ para metidation oxon para os homogeneizados das duas populações de ácaros ( $\mathrm{S}$ e R) foram determinados pelo método de pré-inibição (Hama, 1983), como descrito a seguir. Os testes de inibição foram conduzidos em placas de 96 poços.

Dez $\mu \mathrm{l}$ de cada homogeneizado ( $\mathrm{S}$ ou $\mathrm{R}$ ) foram colocados em cada poço da placa. A inibição foi iniciada com a adição de $5 \mu$ d do inibidor (diversas concentrações: de $2,8 \times 10^{-8}$ a $1,7 \times 10^{-5} M$, em solução de acetona), em cada poço, e mais $5 \mu l$ da solução tampão. Para cada concentração do inibidor, foram utilizados 3 poços. Após $30 \mathrm{~min}$, a $25^{\circ} \mathrm{C}$ (placa mantida em "banho-maria"), a inibição foi interrompida com a adição de $200 \mu \mathrm{l}$ de uma mistura contendo solução tampão (0,1 M MOPS, pH 7,5); DTNB $\left(0,4 \times 10^{-3} M\right)$; $\mathrm{NaHCO}_{3}$ $\left(0,7 \times 10^{-3} \mathrm{M}\right)$; e iodeto de acetiltiocolina $\left(2,5 \times 10^{-3} \mathrm{M}\right)$.

Em seguida, realizou-se o monitoramento das atividades residuais de $\mathrm{ACoE}$, através de um leitor de micro placa a $405 \mathrm{~nm}$. As leituras foram feitas aos 0 e $30 \mathrm{~min}$. No intervalo entre as leituras, a placa foi mantida em "banho-maria" $\left(25^{\circ} \mathrm{C}\right)$. Os dados foram analisados através da análise de Probit. Este experimento foi repetido 3 vezes (totalizando 9 repetições). 


\subsection{Penetração cuticular}

A penetração cuticular de metidation em $A$. womersleyi foi avaliada utilizando-se a metodologia descrita por Foumier et al. (1987a), com modificações. Lotes de 100 ácaros fềmeas foram colocados em tubos de vidro de $4 \mathrm{ml}$, adicionando-se em seguida $1 \mathrm{ml}$ de solução metanólica de [Tiadiazol-2- ${ }^{14} \mathrm{C}$ ]-metidation a 100 ppm (5.000.000 dpm).

Após a imersão em solução inseticida, os ácaros foram recolhidos imediatamente com pipeta Pasteur e colocados sobre a superficie de uma tela de aço (malha 150). Abaixo desta tela, colocou-se um pedaço de papel de filtro para remover o excesso do inseticida marcado.

Após a secagem, os ácaros foram transferidos para o interior de um tubo de vidro de $20 \mathrm{ml}$, com o auxílio de um pincel de pêlo macio.

Os ácaros foram transferidos para os tubos de vidro (com tampa), para evitar a fuga dos ácaros que começavam a se mover poucos minutos após o tratamento com inseticida.

Cada lote de 100 ácaros permaneceu no tubo de vidro por 1, 30 ou 60 min após o tratamento. Após este período, os fitoseídeos foram transferidos para a superficie de um filtro de vidro (acoplado a um funil), onde foram lavados com hexano, para a remoção do inseticida remanescente na cutícula dos ácaros. Neste caso, quanto menor a penetração do inseticida através da cutícula, maior a quantidade do inseticida remanescente.

Foram realizadas duas lavagens dos ácaros com $3 \mathrm{ml}$ do solvente. Os líquidos resultantes da primeira e da segunda lavagem foram coletados separadamente em dois frascos de cintilação líquida, adicionando-se em seguida o cintilador (Aquasol-2, Universal LSC Cocktail).

A quantificação da radioatividade (dpm), no líquido de lavagem, foi realizada através do uso de contador de cintilação líquida (ALOKA Liquid Scintillation Counter LSC-5100). A leitura de cada amostra durou $10 \mathrm{~min}$.

O experimento foi repetido 4 vezes, sendo que, os dados foram analisados através do teste $t(\alpha=0,05)$. 


\subsection{Metabolismo "in vitro" de metidation}

Este estudo foi conduzido, usando-se a metodologia descrita por Foumier et al. (1987a), com modificações. Lotes de 100 fềmeas de cada população ( $\mathrm{S}$ ou R) foram homogeneizados separadamente em $500 \mu 1$ de solução tampão (Tris a $10 \mathrm{~m} M$, pH 7,4), resfriado em gelo, contendo $150 \mathrm{~m} M$ de $\mathrm{KCl}, 100 \mathrm{~m} M$ de EDTA e $20 \%$ de glicerol. A homogeneização foi feita com homogeneizador de vidro (bastão de homogeneização e recipiente de vidro), cuja capacidade do recipiente era de $1 \mathrm{ml}$.

O homogeneizado foi centrifugado por $10 \mathrm{~min}$ a $10.000 \mathrm{~g}$ (gravidades), sendo que, o sobrenadante resultante foi utilizado como fonte de enzimas.

Este sobrenadante foi em seguida centrifugado a $100.000 \mathrm{~g}$ por $2 \mathrm{~h}$ (com ultracentrifuga, Hitachi 55P-7). O sobrenadante obtido foi utilizado como fração solúvel. No caso desta fração, comparou-se o efeito da adição ou não de GSH (forma reduzida de glutatiom) a $2 \mathrm{mM}$ (concentração final). O GSH é um cofator requerido pelas GSH transferases.

O pélete originário desta segunda centrifugação foi dissolvido em $250 \mathrm{~m} M$ de solução tampão fosfatado, $\mathrm{pH} 7,2$, contendo albumina de soro de bovino a $1 \%$ e 7,5 $\mathrm{m} M$ de NADPH ( $\beta-N A D P H-4 ~ N a$, forma reduzida, sal tetrasódico). O pélete obtido da homogeneização de cada 100 fềmeas foi dissolvido em $500 \mu$ deste tampão fosfatado, constituindo a fração microssomal.

As reações metabólicas foram conduzidas utilizando-se $500 \mu \mathrm{l}$ de uma das frações (solúvel ou microssomal), que foram colocadas em tubos de vidro (capacidade de $20 \mathrm{ml}$ ) que haviam sido tratados internamente (filme seco) com $5 \mu$ de uma solução metanólica de $\left[{ }^{14} \mathrm{C}\right]$-metidation $(6.000 \mathrm{dpm})$. Neste caso, o inseticida marcado foi colocado no fundo do tubo e deixado para secar, antes da adição do homogeneizado de ácaros. Este procedimento foi adotado para evitar um possível efeito do solvente (metanol) sobre as enzimas dos ácaros.

O período de incubação foi de $5 \mathrm{~h}$ a $24^{\circ} \mathrm{C}$ ("banho maria"). Após este período, os metabólitos solúveis em água foram separados do metidation através de 3 extrações com clorofórmio e quantificados com um contador de cintilação líquida. 
O experimento foi repetido 3 vezes e os resultados foram submetidos ao teste $t(\alpha=$ $0,05)$.

\subsubsection{Determinação da concentração de proteína}

A determinação da concentração de proteína foi realizada como descrito anteriormente (item 3.7.2). Neste caso, foram utilizadas alíquotas do sobrenadante do homogeneizado dos ácaros após a primeira centrifugação ( $10.000 \mathrm{~g}$ por 10 minutos).

\subsection{Testes toxicológicos com diferentes pesticidas}

Neste estudo, comparou-se a suscetibilidade das 2 populações de $A$. womersleyi, (S e R) a diversos pesticidas utilizados em chá no Japão.

As populações $\mathrm{S}$ e $\mathrm{R}$ utilizadas nesta pesquisa foram aquelas selecionadas com metidation, respectivamente para suscetibilidade e para resistência ao produto

Os pesticidas testados foram: metidation (Supracid CE, 40\%), acefato (Ortran PM, $50 \%$ ), malation (Malathon CE, $50 \%$ ), clorpirifós (Dursban CE, 40\%), diclorvós (DDVP CE, 50\%), bifenthrin (Talstar FW, 7,2\%), fluvalinate (Mavrik PM, 20\%) e piridaben (Sanmite PM 20\%).

A avaliação dos níveis de resistência dos ácaros predadores aos produtos acima referidos, com exceção dos piretróides, foi realizada através da aplicação dos pesticidas diretamente sobre os ácaros, colocados em uma arena de disco de folha de feijão, seguindo a metodologia descrita anteriormente (3. 3 Testes toxicológicos).

No caso dos piretróides, bifenthrin e fluvalinate, a pulverização foi realizada diretamente sobre as fềmeas, colocadas sobre um disco de folha de feijão com $2,5 \mathrm{~cm}$ de diâmetro. Esta folha foi mantida sobre um papel de filtro úmido, em uma placa de Petri. Ao redor da folha foi colocada uma barreira de algodão úmido. Esta barreira foi colocada sem tocar a borda da folha para possibilitar a remoção desta folha, da superfície do papel de filtro. 
Imediatamente após a aplicação, este disco de folha, juntamente com os ácaros, foi colocado no centro de um disco de folha de feijão, cujo diâmetro era de $5 \mathrm{~cm}$, com o auxílio de uma pinça de ponta fina, havendo assim uma margem de $2,5 \mathrm{~cm}$ de folha não tratada ao redor da folha tratada com o piretróide. Esta metodologia foi adotada para estes inseticidas, devido ao efeito de repelência destes piretróides aos ácaros predadores.

Foram utilizadas 5 a 7 concentrações de cada produto, para se estabelecer as curvas de regressão concentração-mortalidade. 


\section{RESULTADOS E DISCUSSÃO}

\subsection{Seleção artificial para resistência e suscetibilidade}

Os resultados das seleções para resistência e suscetibilidade podem ser observados nas tabelas 1 e 2 . Antes do início das seleções, a população mais resistente de $A$. womersleyi mostrava-se 16 vezes mais resistentes a metidation que a população mais suscetível, comparando-se as concentrações letais médias. Tanto a seleção para resistência como a seleção para suscetibilidade mostraram-se efetivas para alteração das suscetibilidades das duas populações do predador. Após 4 seleções artificiais para aumento da resistência, a concentração letal média $\left(\mathrm{CL}_{50}\right)$ para a população resistente $(\mathrm{R})$ passou de 152 ppm para 608 ppm. Com relação à população suscetível, após 3 seleções para suscetibilidade, houve uma redução da $\mathrm{CL}_{50}$ de 9,48 ppm para 1,78 ppm.

Comparando-se as duas populações de ácaros predadores, após as seleções, a razão de resistência ( $\mathrm{R} / \mathrm{S}$ ao nível de $\mathrm{CL}_{50}$ ) cresceu de 16 para 342 vezes.

Hamamura (1987) também obteve sucesso com a seleção para aumento da resistência a metidation, trabalhando com esta mesma espécie de acaro predador. Embora este autor não tenha realizado a seleção para suscetibilidade, seu biótipo suscetível do ácaro predador (coletado de Clerodendron trichotomum) era mais sensível ao inseticida que o biótipo suscetível utilizado no presente trabalho (população inicial coletada de plantas de feijão). Foumier et al. (1988) também realizaram a seleção tanto para resistência como para suscetibilidade a metidation, porém utilizando a espécie $P$. persimilis. Houve uma rápida resposta à seleção para resistência, com aumento da $\mathrm{CL}_{50}$ a cada geração. Entretanto, no caso da seleção para suscetibilidade, os autores não observaram redução significativa da 
Tabela 1. Seleção para resistência e suscetibilidade de duas populações de Amblyseius womersleyi a metidation. Número total de ácaros selecionados e mortalidade.

\begin{tabular}{cccc}
\hline $\begin{array}{c}\text { Pressão de Seleção } \\
\text { Número }\end{array}$ & $\begin{array}{c}\text { Concentração } \\
(\mathrm{ppm})\end{array}$ & $\begin{array}{c}\text { Número de } \\
\text { Fêmeas Selecionadas }\end{array}$ & $\begin{array}{c}\text { Mortalidade } \\
(\%)\end{array}$ \\
\hline \multicolumn{4}{c}{ Para Resistência } \\
1 & 200 & 1250 & 57 \\
2 & 300 & 850 & 62 \\
3 & 400 & 1120 & 56 \\
4 & 500 & 1050 & 65 \\
& & & \\
& & & 36 \\
1 & & & 41 \\
2 & & 500 & 32 \\
\hline
\end{tabular}


Tabela 2. Seleção para resistência e suscetibilidade, de duas populações de Amblyseius womersleyi a metidation. Número total de ácaros utilizados para a obtenção das curvas de concentração-mortalidade; estimativa da $\mathrm{CL}_{50}$ (ppm) e intervalo de confiança (I.C.) a 95\%; coeficiente angular e erro padrão da média (EPM); Qui-quadrado $\left(\chi^{2}\right)$; grau de liberdade (G.L.).

\begin{tabular}{|c|c|c|c|c|c|c|}
\hline $\begin{array}{c}\text { Pressão de } \\
\text { Seleção } \\
\text { Número } \\
\end{array}$ & $\begin{array}{l}\text { Concentração } \\
(\mathrm{ppm})\end{array}$ & $\begin{array}{l}\text { Número } \\
\text { Ácaros }\end{array}$ & $\begin{array}{c}\mathrm{CL}_{50} \\
(95 \% \text { I.C. })\end{array}$ & $\begin{array}{c}\text { Coeficiente } \\
\text { Angular } \\
\pm \text { EPM }\end{array}$ & $\chi^{2}$ & G.L. \\
\hline \multicolumn{7}{|c|}{ Para Resistência } \\
\hline${ }^{1} 0$ & - & 277 & $\begin{array}{c}152 \\
(123-228)\end{array}$ & $2,13 \pm 0,69$ & 2,10 & 3 \\
\hline 1 & 200 & 277 & $\begin{array}{c}284 \\
(247-332)\end{array}$ & $3,29 \pm 0,096$ & 0,21 & 3 \\
\hline 2 & 300 & 339 & $\begin{array}{c}335 \\
(294-381)\end{array}$ & $3,42 \pm 0,34$ & 2,57 & 4 \\
\hline 3 & 400 & 374 & $\begin{array}{c}467 \\
(415-533)\end{array}$ & $3,66 \pm 0,24$ & 0,59 & 3 \\
\hline 4 & 500 & 291 & $\begin{array}{c}608 \\
(530-704) \\
\end{array}$ & $3,16 \pm 0,15$ & 0,92 & 3 \\
\hline \multicolumn{7}{|c|}{ Para Suscetibilidade } \\
\hline${ }^{1} 0$ & - & 285 & $\begin{array}{c}9,48 \\
(7,80-11,8)\end{array}$ & $1,89 \pm 0,20$ & 2,88 & 3 \\
\hline 1 & 8 & 276 & $\begin{array}{c}5,50 \\
(4,65-6,61)\end{array}$ & $2,44 \pm 0,19$ & 2,43 & 3 \\
\hline 2 & 4 & 453 & $\begin{array}{c}2,58 \\
(2,24-3,03)\end{array}$ & $2,57 \pm 0.24$ & 7,49 & 4 \\
\hline 3 & 2 & 338 & $\begin{array}{c}1,78 \\
(1,50-2,13)\end{array}$ & $2,27 \pm 0,15$ & 2,70 & 4 \\
\hline
\end{tabular}

'Antes da seleção 
resistência ao inseticida, após 7 seleções com metidation, em concetrações equivalentes a $\mathrm{CL}_{50}$ estimada. Neste caso, os autores utilizaram uma população inicial de 60 fềmeas grávidas de $P$. persimilis.

Yamamoto et al. (1995) verificaram apenas uma pequena redução na suscetibilidade de $P$. citri ao acaricida hexythiazox, após realizarem 5 seleções para suscetibilidade ao acaricida. Esta baixa eficiência na seleção foi atribuída a uma possível baixa frequeência do gene para resistência a hexythiazox, na população original não selecionada.

\subsection{Testes toxicológicos com tubo de vidro e arena de folha}

A mortalidade dos ácaros predadores das duas populações ( $\mathrm{R} \mathrm{e} \mathrm{S}$ ) foi pouco maior, quando os ácaros entraram em contato com o inseticida metidation no interior do tubo de vidro, do que quando receberam o produto via pulverização sobre arena de folha de feijão (Tabela 3).

Uma das principais diferenças, entre estes dois métodos, seria a presença de alimento (T. urticae), no caso da arena de folha. Além disso, os ácaros predadores estariam sobre um substrato natural (folha de feijão) com água em abundância.

A presença de água e alimento na arena de folha faz com que seja possível a avaliação da toxicidade de um pesticida por um período relativamente longo, como 48 ou $72 \mathrm{~h}$. utilizando-se este método.

No presente experimento, a avaliação da mortalidade de $A$. womersleyi no teste com arena foi realizado após $48 \mathrm{~h}$ da pulverização, porém não se observou nenhum aumento significativo da mortalidade após $24 \mathrm{~h}$ do tratamento com metidation.

No caso do teste com tubo de vidro, a maior porcentagem de mortalidade ácaros fitoseídeos ocorreu entre 12 e $18 \mathrm{~h}$ após a colocação dos ácaros no interior dos tubos tratados com metidation; o que permitiu a avaliação da mortalidade após um período de 24 h. Na testemunha (sem tratamento), a porcentagem de mortalidade foi inferior a $10 \%$, em ambos os testes 
Tabela 3. Efeito de metidation, em duas populações ( $\mathrm{S}$ e R) de Amblyseius womersleyi, colocando-se os ácaros em tubo de vidro de $10 \mathrm{~cm} \times 1,2 \mathrm{~cm}$ tratado internamente com metidation, ou em arena de folha de feijão tratada através de pulverização realizada diretamente sobre os ácaros. Número total de ácaros utilizados para a obtenção das curvas de concentraçãomortalidade; estimativa da $\mathrm{CL}_{50}$ (ppm) e intervalo de confiança (I.C.) a 95\%; coeficiente angular e erro padrão da média (EPM); Qui-quadrado $\left(\chi^{2}\right)$; grau de liberdade (G.L.); razão de resistência (RR).

\begin{tabular}{|c|c|c|c|c|c|c|}
\hline População & $\begin{array}{c}\text { Número } \\
\text { Ácaros }\end{array}$ & $\begin{array}{c}\mathrm{CL}_{50} \\
(95 \% \text { I.C. })\end{array}$ & $\begin{array}{c}\text { Coeficiente } \\
\text { Angular } \\
\pm \text { EPM }\end{array}$ & $\chi^{2}$ & G.L. & $\overline{\mathrm{RR}}$ \\
\hline \multicolumn{7}{|c|}{ Teste em tubo de vidro } \\
\hline${ }^{2} \mathrm{~S}$ & 470 & $\begin{array}{c}1,07 \\
(0,89-1,33)\end{array}$ & $1,69 \pm 0,079$ & 0,971 & 4 & 1 \\
\hline${ }^{3} \mathrm{R}$ & 473 & $\begin{array}{c}324 \\
(284-375)\end{array}$ & $2,80 \pm 0,19$ & 5,410 & 4 & 303 \\
\hline \multicolumn{7}{|c|}{ Teste em arena de folha } \\
\hline $\mathrm{S}$ & 453 & $\begin{array}{c}2,58 \\
(2,24-3,03)\end{array}$ & $2,57 \pm 0.24$ & 7,489 & 4 & 1 \\
\hline $\mathrm{R}$ & 374 & $\begin{array}{c}467 \\
(415-533)\end{array}$ & $3,66 \pm 0.24$ & 0,593 & 3 & 181 \\
\hline
\end{tabular}

${ }^{1} \mathrm{RR}=$ Razão de Resistência $=\mathrm{CL}_{50}$ população resistente/CL $\mathrm{L}_{50}$ população suscetível ${ }^{2}$ População suscetível $=$ selecionada para suscetibilidade com 4 ppm de metidation ${ }^{3}$ População resistente $=$ selecionada para resistência com 400 ppm de metidation 
Comparando-se as razões de resistência ( $\mathrm{R} / \mathrm{S}$ ao nivel de $\mathrm{CL}_{50}$ ) para os dois métodos, observou-se, para o teste com arena, uma $R R$ igual a 181 vezes, enquanto que, no caso do tubo de vidro, a RR foi de 303 vezes. Neste aspecto, o teste com tubo de vidro foi mais eficiente para detectar diferenças entre as taxas de resistência das populações suscetível e resistente, em relação ao outro teste (Tabela 3).

Considerando-se, porém, o coeficiente angular da curva, verificou-se um valor maior deste coeficiente no teste com arena de folha. para as duas populações ( $\mathrm{S}$ e R), indicando que estes dados seriam mais fidedignos (maior homogeneidade), em relação aos do teste com tubo de vidro.

Overmeer (1985) descreveu vários testes toxicológicos para ácaros predadores de importância econômica e destacou que os diversos métodos podem apresentar resultados diferentes quando se pretende comparar a resistência a pesticidas entre duas ou mais

populações de ácaros. Neste aspecto, Dennehy et al. (1983), trabalhando com ácaro rajado, T. urticae, mencionaram uma diferença de apenas 5,7 vezes na resistência a dicofol entre uma população resistente e uma suscetível, utilizando o método de mergulho de lâminas, enquanto que, esta diferença foi de 544 vezes, utilizando o método de contato residual.

Estes resultados indicaram que o uso do tubo de vidro era viável para avaliação da resistência de $A$. womersleyi a metidation, podendo assim ser adotado nos experimentos com sinergistas.

\subsection{Testes toxicológicos utilizando sinergistas}

\subsubsection{Teste 1 com sinergistas}

\subsubsection{Estimativa da "concentração subletal máxima" para sinergistas}

Pela Tabela 4, pode-se observar que todos os sinergistas mostraram-se tóxicos a $A$. womersleyi, quando os ácaros foram expostos a concentrações elevadas destes produtos, via contato residual no interior dos tubos de vidro. 
Tabela 4. Estimativa da "concentração subletal máxima" para os sinergistas PBO (butóxido de piperonila), DEM (dietil maleato), DEF (S,S,S tributilfosforotritioato), em uma população suscetível de Amblyseius womersleyi a metidation.

\begin{tabular}{|c|c|c|c|c|c|c|c|c|}
\hline \multicolumn{3}{|c|}{$\mathrm{PBO}$} & \multicolumn{3}{|c|}{$\overline{\mathrm{DEM}}$} & \multicolumn{3}{|c|}{ DEF } \\
\hline $\begin{array}{l}\text { Tonc. } \\
\mathrm{mg} / \mathrm{ml}\end{array}$ & $\begin{array}{c}\mathrm{N}^{\circ} \\
\text { Ácaros }\end{array}$ & $\begin{array}{l}{ }^{2} \text { Mort. } \\
\text { (\%) }\end{array}$ & $\begin{array}{l}\text { Conc. } \\
\mathrm{mg} / \mathrm{ml}\end{array}$ & $\begin{array}{c}\mathrm{N}^{\circ} \\
\text { Ácaros }\end{array}$ & $\begin{array}{l}\text { Mort. } \\
(\%)\end{array}$ & $\begin{array}{l}\text { Conc. } \\
\mathrm{mg} / \mathrm{ml}\end{array}$ & $\begin{array}{c}\mathrm{N}^{\circ} \\
\text { Ácaro } \\
\mathrm{s}\end{array}$ & $\begin{array}{l}\text { Mort. } \\
(\%)\end{array}$ \\
\hline 8,45 & 79 & 100 & 4,30 & 76 & 100 & 0,64 & 79 & 100 \\
\hline 4,22 & 77 & 75,3 & 2,15 & 77 & 94,8 & 0,32 & 77 & 96,1 \\
\hline 2,11 & 75 & 45,3 & 1,08 & 78 & 75,6 & 0,16 & 79 & 65,8 \\
\hline 1,06 & 78 & 9,0 & 0,54 & 79 & 46,8 & 0,08 & 76 & 40,8 \\
\hline 0,53 & 79 & 8,9 & 0,27 & 75 & 10,7 & 0,04 & 75 & 38,7 \\
\hline 0,26 & 80 & 7,5 & 0,13 & 79 & 11,4 & 0,02 & 79 & 8,9 \\
\hline 0,0 & 77 & 7,8 & 0,0 & 78 & 5,1 & 0,0 & 78 & 6,4 \\
\hline
\end{tabular}

${ }^{\mathrm{T}}$ Concentração do sinergista diluído em acetona.

${ }^{2}$ Porcentagem de mortalidade não corrigida. 
As concentrações subletais máximas foram estimadas em 1,06; 0,27; e 0,02 mg/ml, respectivamente para os sinergistas PBO (butóxido de piperonila), DEM (dietil maleato) e DEF (S,S,S tributilfosforotritioato).

Vidal \& Kreiter (1995) estimaram uma concentração subletal máxima de 0,70 $\mathrm{mg} / \mathrm{ml}$ para $\mathrm{PBO}$, e de $0,04 \mathrm{mg} / \mathrm{ml}$ para $\mathrm{DEF}$, utilizando uma população de $P$. persimilis suscetível a inseticidas. Neste experimento, os ácaros predadores também foram expostos aos sinergistas via contato residual.

\subsubsection{Bioensaio}

Os resultados do experimento sobre o efeito de sinergistas na toxicidade de metidation em $A$. womersleyi, estão presentes na Tabela 5 .

O maior efeito sinergístico foi observado para PBO (inibidor de oxidases com funções múltiplas), sobre a população resistente do ácaro, com uma razão de sinergismo de 12,3 vezes. Este sinergista apresentou um efeito bem menor sobre a toxicidade do metidation, quando utilizado na população suscetível do fitoseídeo $(\mathrm{RS}=1,61)$, indicando que, pelo menos parcialmente, a degradação oxidativa estaria envolvida na resistência destes ácaros a metidation.

A razão de resistência, verificada nos tratamentos com $\mathrm{PBO}(\mathrm{RR}=39,4$ vezes), está longe de explicar a diferença na resistência entre os ácaros das populações resistente e suscetível $(\mathrm{RR}=303$ vezes). Neste caso, um outro mecanismo de resistência, como o da alteração no alvo de ação, poderia estar envolvido nesta resistência. Porém, uma outra possibilidade seria relacionada à eficiência do método; nesta hipótese, a técnica utilizada não teria sido suficientemente adequada para detectar todo o potencial de desintoxicação via degradação oxidativa, envolvendo as monooxigenases do citocromo P-450.

Uma das formas de se aumentar a eficiência do método seria possivelmente elevar a concentração do sinergista $\mathrm{PBO}$, no tratamento dos ácaros da população resistente. Uma outra alternativa seria testar um outro inibidor de oxidases com funções múltiplas (ofm) que apresentasse maior dificuldade para ser degradada pelos ácaros resistentes. Estas 
Tabela 5. Efeito de metidation, com ou sem sinergista, nas populações suscetível e resistente de Amblyseius womersleyi. Número total de ácaros utilizados para a obtenção das curvas de concentração-mortalidade; estimativa da $\mathrm{CL}_{50}$ (ppm) e intervalo de confiança (I.C.) a $95 \%$; coeficiente angular e erro padrão da média (EPM); Qui-quadrado $\left(\chi^{2}\right)$; grau de liberdade (G.L.); razão de resistência (RR); razão de sinergismo (RS).

\begin{tabular}{|c|c|c|c|c|c|c|c|}
\hline $\begin{array}{c}\text { População } \\
(+ \text { Sinergista })\end{array}$ & $\begin{array}{l}\text { Número } \\
\text { Ácaros }\end{array}$ & $\begin{array}{c}C L_{50} \\
(95 \% \text { I.C. })\end{array}$ & $\begin{array}{c}\text { Coeficiente } \\
\text { Angular } \\
\pm \text { EPM }\end{array}$ & $\chi^{2}$ & G.L. & RR & ${ }^{2} \mathrm{RS}$ \\
\hline${ }^{3} S$ & 470 & $\begin{array}{c}1,07 \\
(0,89-1,33)\end{array}$ & $1,69 \pm 0,079$ & 0,97 & 4 & 1 & - \\
\hline $\mathrm{S}+\mathrm{PBO}$ & 458 & $\begin{array}{c}0,67 \\
(0,54-0,87)\end{array}$ & $1,69 \pm 0,15$ & 5,03 & 4 & - & 1,61 \\
\hline$S+D E M$ & 473 & $\begin{array}{c}0,92 \\
(0,76-1,14)\end{array}$ & $1,78 \pm 0,18$ & 7,21 & 4 & - & 1,17 \\
\hline$S+D E F$ & 461 & $\begin{array}{c}0,81 \\
(0,65-1,07)\end{array}$ & $1,42 \pm 0,14$ & 4,32 & 4 & - & 1,32 \\
\hline${ }^{4} \mathrm{R}$ & 473 & $\begin{array}{c}324 \\
(283-375)\end{array}$ & $2,80 \pm 0,19$ & 5,41 & 4 & ${ }^{1} 303$ & - \\
\hline$R+P B O$ & 633 & $\begin{array}{c}26,4 \\
(22,2-31,8)\end{array}$ & $1,69 \pm 0,077$ & 3,47 & 6 & ${ }^{5} 39,4$ & 12,3 \\
\hline$R+D E M$ & 550 & $\begin{array}{c}87,3 \\
(71,2-111)\end{array}$ & $1,50 \pm 0,15$ & 9,23 & 5 & ${ }^{6} 94,9$ & 3,72 \\
\hline$R+D E F$ & 554 & $\begin{array}{c}137 \\
(115-166)\end{array}$ & $1,64 \pm 0,18$ & 9,32 & 5 & ${ }^{7} 169$ & 2,37 \\
\hline
\end{tabular}

${ }^{1} R R=$ Razão de Resistência $=C_{50}$ população resistente/CL $L_{50}$ população suscetível

${ }^{2} \mathrm{RS}=$ Razão de Sinergismo $=\mathrm{CL}_{50}$ sem sinergista $/ \mathrm{CL}_{50}$ com sinergista

${ }^{3}$ População suscetível $=$ selecionada para suscetibilidade com 4 ppm de metidation

${ }^{4}$ População resistente $=$ selecionada para resistência com 400 ppm de metidation

${ }^{5} \mathrm{CL}_{50}(\mathrm{R}+\mathrm{PBO}) / \mathrm{CL}_{50}(\mathrm{~S}+\mathrm{PBO})$

${ }^{6} \mathrm{CL}_{50}(\mathrm{R}+\mathrm{DEM}) / \mathrm{CL}_{50}(\mathrm{~S}+\mathrm{DEM})$

${ }^{7} \mathrm{CL}_{50}(\mathrm{R}+\mathrm{DEF}) / \mathrm{CL}_{50}(\mathrm{~S}+\mathrm{DEF})$ 
hipóteses levaram à realização de um novo experimento (Teste 2) com PBO, comparandose o mesmo com outro inibidor de ofm, PTPE (2-propinil 2,3,6-triclorofenil eter).

Roush \& Plapp (1982) também mencionaram uma atividade maior das oxidases com funções múltiplas, em uma população de $M$. occidentalis resistente a inseticidas carbamatos (carbaryl, propoxur), realizando o tratamento destes ácaros fitoseídeos com os inseticidas em mistura com PBO. Em um outro teste, estes autores observaram maior taxa de conversão de heptacloro para epóxido de heptacloro nestes ácaros resistentes, em relação aos suscetíveis.

Com relação à oxidação de organofosforados, dois fenômenos interessantes complicam o estudo das ofrn na resistência de artrópodos a pesticidas. Foi observado em populações resistentes de mosca doméstica que as ofm não atuavam apenas na reação de desintoxicação, mas também poderiam ser responsáveis pela ativação das formas PS do inseticida para a forma PO. A ativação atuava no sentido de aumentar a sensibilidade da mosca ao organofosforado, mas este fenômeno normalmente era anulado pela desintoxicação (Oppennorth, 1985). Fournier et al. (1987a) reportaram que as ofm das populações de $P$. persimilis resistentes a metidation eram importantes para a ativação do inseticida, baseando-se no fato do sinergista PBO reduzir a toxicidade do inseticida na população resistente do ácaro predador.

Além do PBO, também se observou algum efeito sinergístico para DEF (inibidor de esterases e GSH transferases) e DEM (inibidor de GSH transferases e monooxigenases), quando utilizados na população resistente de $A$. womersleyi. As razões de sinergismo para DEF e DEM foram respectivamente de 2,37 e 3,72, para esta população resistente. O efeito destes sinergistas (DEF e DEM) sobre a população suscetível não foi significativo, com razões de sinergismo inferiores a 1,4 (Tabela 5).

A razão de resistência foi reduzida de 303 vezes para 169 vezes, quando os ácaros receberam o tratamento prévio com $\mathrm{DEF}$. $\mathrm{O}$ fato da razão de resistência ainda ter se mantido relativamente alta indica que a contribuição das esterases na resistência de $A$. womersleyi a metidation é pequena.

Entretanto, esterases e S-transferases de glutatiom foram relacionadas com a resistência de A. fallacis a organofosforados (Mullin et al., 1982). Scott et al. (1983) 
também mencionaram o envolvimento de esterases na resistência de A. fallacis a azinfós-metílico.

Vidal \& Kreiter (1995) não observaram um aumento significativo da toxicidade de paration metílico em T. pyri, realizando um tratamento prévio com DEF em uma população resistente deste fitoseídeo.

\subsubsection{Teste 2 com sinergistas}

\subsubsection{Estimativa da "concentração subletal máxima" para sinergistas}

Neste experimento, comparou-se a toxicidade dos sinergistas PBO e PTPE (ambos inibidores de ofm) sobre as populações $\mathrm{S}$ e $\mathrm{R}$ de $A$. womersleyi (Tabela 6).

O teste com PBO foi repetido para a população suscetível pelo fato da população utilizada neste teste (selecionada com metidation a $2 \mathrm{ppm}$ ) ser mais suscetível a metidation que a do teste 1 (selecionada com metidation a 4 ppm). Esta menor suscetibilidade ao inseticida poderia afetar a sensibilidade da população ao sinergista.

No caso do PBO, a população resistente mostrou-se ligeiramente mais tolerante ao sinergista que a população suscetível, apresentando uma concentração subletal máxima duas vezes maior $(2,11 \mathrm{mg} / \mathrm{ml})$. A concentração subletal máxima estimada para a população suscetível foi a mesma obtida no teste anterior (teste 1), sendo equivalente a 1,06 $\mathrm{mg} / \mathrm{ml}$.

O PTPE mostrou-se bem mais tóxico ao ácaro predador que $\mathrm{PBO}$, tendo sido estimada uma concentração subletal máxima de $0,016 \mathrm{mg} / \mathrm{ml}$, para a população suscetível. A população resistente mostrou-se 4 vezes mais tolerante ao sinergista, com uma concentração subletal máxima de $0,062 \mathrm{mg} / \mathrm{ml}$. 
Tabela 6. Estimativa da "concentração subletal máxima" para os sinergistas PBO (butóxido de piperonila) e PTPE (2-propinil 2,3,6-triclorofenil eter), nas populações suscetível e resistente de Amblyseius womersleyi.

\begin{tabular}{|c|c|c|c|c|c|}
\hline $\begin{array}{c}\text { Concentração } \\
\mathrm{mg} / \mathrm{ml}\end{array}$ & $\begin{array}{l}\text { Número } \\
\text { Ácaros }\end{array}$ & $\begin{array}{c}{ }^{2} \text { Mortalidade } \\
(\%)\end{array}$ & $\begin{array}{c}\text { Concentração } \\
\mathrm{mg} / \mathrm{ml}\end{array}$ & $\begin{array}{l}\text { Número } \\
\text { Ácaros } \\
\end{array}$ & $\begin{array}{c}\text { Mortalidade } \\
(\%) \\
\end{array}$ \\
\hline \multicolumn{6}{|l|}{ PBO } \\
\hline & Suscetível & & & Resistente & \\
\hline - & - & - & 16,9 & 77 & 75,3 \\
\hline 8,45 & 75 & 89,3 & 8,45 & 79 & 49,4 \\
\hline 4,23 & 75 & 61,3 & 4,23 & 79 & 26,6 \\
\hline 2,11 & 80 & 35,0 & 2,11 & 75 & 8,0 \\
\hline 1,06 & 76 & 6,6 & 1,06 & 74 & 6,7 \\
\hline 0,53 & 74 & 5,4 & 0,52 & 74 & 4,0 \\
\hline 0,0 & 79 & 6,3 & 0,0 & 75 & 4,0 \\
\hline \multicolumn{6}{|l|}{ PTPE } \\
\hline & Suscetível & & & Resistente & \\
\hline - & - & - & 0,25 & 76 & 75,0 \\
\hline 0,12 & 80 & 92,5 & 0,12 & 75 & 41,3 \\
\hline 0,062 & 75 & 60,0 & 0,062 & 77 & 9,1 \\
\hline 0,031 & 75 & 38,7 & 0,031 & 78 & 7,6 \\
\hline 0,016 & 74 & 8,1 & 0,016 & 79 & 7,5 \\
\hline 0,0078 & 76 & 6,5 & 0,0078 & 79 & 5,1 \\
\hline 0,0 & 77 & 6,5 & 0.0 & 74 & 2,7 \\
\hline
\end{tabular}

${ }^{1}$ Concentração do sinergista diluído em acetona.

${ }^{2}$ Porcentagem de mortalidade não corrigida. 
São poucos os trabalhos referentes a PTPE, como um inibidor de monooxigenases (Casida, 1970; Brown et al. 1996). Kasai et al. (1998) compararam a toxicidade deste sinergista em dois biótipos de Culex quinquefasciatus Say e observaram que a população resistente foi 4 vezes mais tolerante ao PTPE que a população suscetível. Além disso, esta população resistente mostrou-se 10 vezes mais tolerante ao $\mathrm{PBO}$. A concentração subletal máxima de PTPE foi semelhante a de PBO para as duas populações estudadas.

\subsubsection{Bioensaio}

Nos tratamentos em que os ácaros resistentes foram expostos aos sinergistas PBO e PTPE, houve um aumento significativo na mortalidade dos ácaros, causada por metidation, em relação ao tratamento sem sinergista (Tabela 7 e Figura 1). Além disso, observou-se um aumento da razão de sinergismo (RS), para ambos os sinergistas, quando estes foram utilizados em uma concentração mais elevada.

O PBO, quando utilizado na menor concentração $(1,06 \mathrm{mg} / \mathrm{ml})$, induziu um aumento de 20,2 vezes na toxicidade do metidation na população R. Esta razão de sinergismo foi relativamente maior que a obtida no Teste 1 (12,3 vezes), porém deve ser considerado que a razão de resistência $(R R)$ obtida no Teste $2(R R=565)$ também foi maior que a observada no Teste $1(\mathrm{RR}=303)$. A maior razão de sinergismo (RS), utilizando-se PBO como sinergista, foi observada para a sua maior concentração $(2,11$ $\mathrm{mg} / \mathrm{ml})$, com RS igual a 34 vezes.

O PTPE mostrou-se um sinergista relativamente mais eficiente que o PBO, apresentando uma RS de 59,3 vezes, quando utilizado na concentração de $0,062 \mathrm{mg} / \mathrm{ml}$, na população resistente de $A$. womersleyi. Esta concentração de PTPE foi $1 / 34$ da concentração de PBO utilizada para a população resistente, neste estudo.

Quando os sinergistas foram utilizados na população suscetível, não foram observadas diferenças significativas na toxicidade do metidation $\left(\mathrm{CL}_{50}\right)$, verificando-se razões de sinergismo inferiores a 1,6. 
Tabela 7. Efeito de metidation, com ou sem sinergista (PBO, PTPE), em duas populações ( $\mathrm{R}$ e $\mathrm{S}$ ) de Amblyseius womersleyi. Número total de ácaros utilizados para a obtenção das curvas de concentração-mortalidade; estimativa da $\mathrm{CL}_{50}(\mathrm{ppm}$ ) e intervalo de confiança (I.C.) a 95\%; coeficiente angular e erro padrão da média (EPM); Qui-quadrado $\left(\chi^{2}\right)$; grau de liberdade (G.L.); razão de resistência (RR); razão de sinergismo (RS).

\begin{tabular}{|c|c|c|c|c|c|c|c|}
\hline $\begin{array}{c}\text { População } \\
(+ \text { Sinergista })\end{array}$ & $\begin{array}{l}\text { Número } \\
\text { Ácaros }\end{array}$ & $\begin{array}{c}\mathrm{CL}_{50} \\
(95 \% \text { I.C. })\end{array}$ & $\begin{array}{c}\text { Coeficiente } \\
\text { Angular } \\
\pm \mathrm{EPM}\end{array}$ & $\chi^{2}$ & G.L & RR & ${ }^{2} \mathrm{RS}$ \\
\hline${ }^{3} \mathrm{~S}$ & 535 & $\begin{array}{c}0,80 \\
(0,64-1,04)\end{array}$ & $1,37 \pm 0,12$ & 6,02 & 5 & 1 & - \\
\hline $\mathrm{S}+\mathrm{PBO}(1,06 \mathrm{mg} / \mathrm{ml})$ & 458 & $\begin{array}{c}0,56 \\
(0,45-0,76)\end{array}$ & $1,35 \pm 0,13$ & 3,74 & 4 & - & 1,41 \\
\hline $\mathrm{S}+\mathrm{PTPE}(0,016 \mathrm{mg} / \mathrm{ml})$ & 466 & $\begin{array}{c}0,50 \\
(0,40-0,66)\end{array}$ & $1,52 \pm 0,15$ & 2,94 & 4 & - & 1,59 \\
\hline${ }^{4} \mathrm{R}$ & 390 & $\begin{array}{c}450 \\
(389-520)\end{array}$ & $2,57 \pm 0,063$ & 0,23 & 3 & ${ }^{1} 565$ & - \\
\hline $\mathrm{R}+\mathrm{PBO}(1,06 \mathrm{mg} / \mathrm{ml})$ & 459 & $\begin{array}{c}22,3 \\
(16,7-29,4)\end{array}$ & $1,04 \pm 0,10$ & 2,61 & 4 & ${ }^{5} 39,8$ & 20,2 \\
\hline $\mathrm{R}+\mathrm{PBO}(2,11 \mathrm{mg} / \mathrm{ml})$ & 464 & $\begin{array}{c}13,2 \\
(10,9-16,2)\end{array}$ & $1,62 \pm 0,19$ & 7,29 & 4 & - & 34,0 \\
\hline $\mathrm{R}+\mathrm{PTPE}(0,016 \mathrm{mg} / \mathrm{ml})$ & 546 & $\begin{array}{c}27,7 \\
(21,8-35,1)\end{array}$ & $1,23 \pm 0,083$ & 2,39 & 5 & ${ }^{6} 55,4$ & 16,2 \\
\hline $\mathrm{R}+\operatorname{PTPE}(0,062 \mathrm{mg} / \mathrm{ml})$ & 538 & $\begin{array}{c}7,59 \\
(6,22-9,35) \\
\end{array}$ & $1,39 \pm 0,048$ & 1,31 & 5 & - & 59,3 \\
\hline
\end{tabular}

$R R=$ Razão de Resistência $=C_{50}$ população resistente/CL $L_{50}$ população suscetível

${ }^{2} \mathrm{RS}=$ Razão de Sinergismo $=\mathrm{CL}_{50}$ sem sinergista/ $\mathrm{CL}_{50}$ com sinergista

'População suscetível = selecionada para suscetibilidade com 2 ppm de metidation

${ }^{4}$ População resistente $=$ selecionada para resistência com 500 ppm de metidation

${ }^{\Sigma} \mathrm{CL}_{50}(\mathrm{R}+\mathrm{PBO}) / \mathrm{CL}_{50}(\mathrm{~S}+\mathrm{PBO}$ a $1,06 \mathrm{mg} / \mathrm{ml})$

${ }^{6} \mathrm{CL}_{50}(\mathrm{R}+\mathrm{PTPE}) / \mathrm{CL}_{50}(\mathrm{~S}+\mathrm{PTPE}$ a $0,016 \mathrm{mg} / \mathrm{ml})$ 


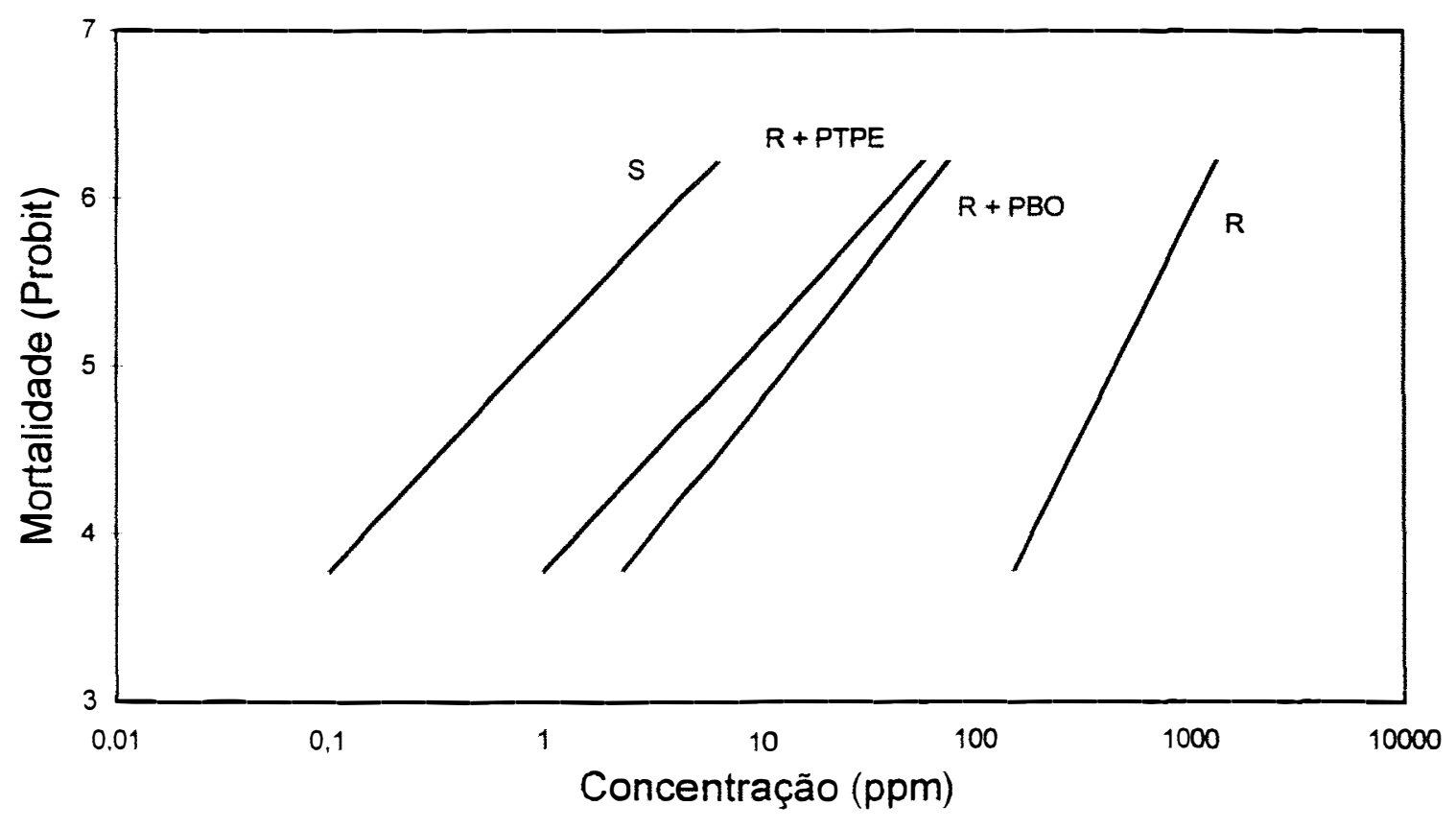

Figura 1. Linhas de mortalidade, obtidas com as populações suscetível (S) e resistente (R) de Amblyseius womersleyi, tratadas com metidation, com ou sem o prétratamento com sinergistas (PBO a $2,11 \mathrm{mg} / \mathrm{ml}$ e PTPE a $0,062 \mathrm{mg} / \mathrm{ml}$ ). 
Estes resultados estão de acordo os resultados obtidos no Teste 1, indicando que, pelo menos parcialmente, as oxidases com funções múltiplas estariam envolvidas nesta resistência de $A$. womersleyi a metidation.

No caso das testemunhas, nas quais os ácaros não receberam nenhum tratamento, ou foram expostos apenas aos sinergistas, a mortalidade foi inferior a $11 \%$, para os testes 1 e 2 com sinergistas.

Kasai et al. (1998) observaram um aumento de 140,8 vezes na toxicidade de permetrina em larvas da população resistente de $C$. quinquefasciatus, quando o inseticida foi aplicado em mistura com PTPE, utilizando a concentração subletal máxima do produto $(5,0 \mu \mathrm{g} / \mathrm{ml})$. Razões de sinergismo bastante elevadas também foram verificadas com o uso de PBO.

Segundo Oppenoorth (1985), a capacidade de desintoxicação pode ser aumentada significativamente por fatores que retardam a intoxicação (tais como a redução na penetração ou a alteração no alvo de ação). Assim sendo, no caso de um inseticida organofosforado, mesmo que a capacidade de desintoxicação por oxidação seja a mesma para os biótipos suscetível e resistente, a oportunidade para a metabolização do inseticida é maior na população resistente quando a inibição da acetilcolinesterase pelo inseticida é mais lenta. Neste caso, o efeito de um sinergista que bloqueia a desintoxicação seria muito maior, o que poderia levar a uma conclusão errada, que a desintoxicação seria o mecanismo de resistência. Portanto, o estudo com sinergistas não seria suficiente para explicar com clareza o mecanismo envolvido na resistência a um determinado inseticida, sendo necessário a combinação de outros métodos (tais como, estudos sobre alteração no alvo de ação ou redução na penetração cuticular) para se tentar esclarecer este mecanismo. 


\subsection{Alteração no alvo de ação}

\subsubsection{Atividade de acetilcolinesterase}

As atividades de ACoE das populações suscetível e resistente de $A$. womersleyi são apresentadas na Tabela 8. Não foram observadas diferenças significativas entre as $K \mathrm{~m}$ e $V \max$ das acetilcolinesterases das duas populações (R e S).

Fournier et al. (1987a) também mencionaram atividades de ACoE semelhantes para as populações suscetível e resistente de $P$. persimilis a metidation.

Embora as atividades de ACoE não tenham se mostrado diferentes, para as populações S e R de A. womersleyi, Anber \& Overmeer (1988) observaram uma diferença de 4,25 vezes entre as atividades de $\mathrm{ACoE}$ das populações resistente e suscetível de $A$. potentillae. Neste caso, a $\mathrm{ACoE}$ da população resistente de $A$. potentillae apresentava a menor atividade $(5,56 \mathrm{nmol} / \mathrm{mg}$ proteína/min), mostrando-se altamente insensível à inibição por inseticidas organofosforados.

\subsubsection{Teste de inibição}

Observou-se uma diferença significativa entre os valores de $\mathrm{I}_{50}$ de populações de $A$. womersleyi resistente e suscetível a metidation (Tabela 9). A concentração do inibidor (metidation oxon) necessária para inibir $50 \%$ da atividade de acetilcolinesterase foi 3 vezes maior na população resistente. Entretanto, verificou-se que as atividades residuais de acetilcolinesterase das duas populações mostraram pequeno contraste, para as concentrações mais elevadas do inibidor (Figura 2). Para a maior concentração do inibidor $\left(17,3 \times 10^{-6} \mathrm{M}\right)$, as atividades residuais de $\mathrm{ACoE}$ foram respectivamente de $24,7 \%$ e $29,4 \%$, para as populações suscetível e resistente deste ácaro predador.

Estes resultados indicam que, embora a redução na sensibilidade de acetilcolinesterase pareça estar parcialmente envolvida na resistência de $A$. womersleyi a metidation, este mecanismo mostrou ser de importância secundária nesta resistência. 
Tabela 8. Atividades de acetilcolinesterase ( $K \mathrm{~m}$ e $V \max )$ das populações de Amblyseius womersleyi suscetível e resistente a metidation.

\begin{tabular}{lll}
\hline População & $\begin{array}{c}{ }^{1} K \mathrm{~m} \pm \mathrm{DP} \\
\left(1 \times 10^{-4} M\right)\end{array}$ & $\begin{array}{l}{ }^{2} V \max \pm \mathrm{DP} \\
(\mathrm{nmol} / \mathrm{mg} \text { proteína/min })\end{array}$ \\
\hline Suscetível & $1,47 \pm 0,09$ & $10,95 \pm 1,29$ \\
Resistente & $1,45 \pm 0,12$ n.s. & $14,04 \pm 1,55$ n.s. $^{3}$ \\
\hline
\end{tabular}

${ }^{1}$ Constante de Michaelis \pm desvio padrão

${ }^{2}$ Velocidade máxima \pm desvio padrão

${ }^{3}$ n.s., não significativo a $5 \%$ de probabilidade pelo teste $t$.

Tabela 9. Inibição de acetilcolinesterase $\left(\mathrm{I}_{50}\right)$ em duas populações de Amblyseius womersleyi, utilizando metidation oxon como inibidor.

\begin{tabular}{ccc}
\hline População & $I_{50}\left(1 \times 10^{-6} M\right)$ & Intervalo de Confiança a 95\% \\
\hline Suscetível & 1,009 & $(0,67-1,55)$ \\
Resistente & 3,027 & $(2,17-4,42)$ \\
\hline
\end{tabular}




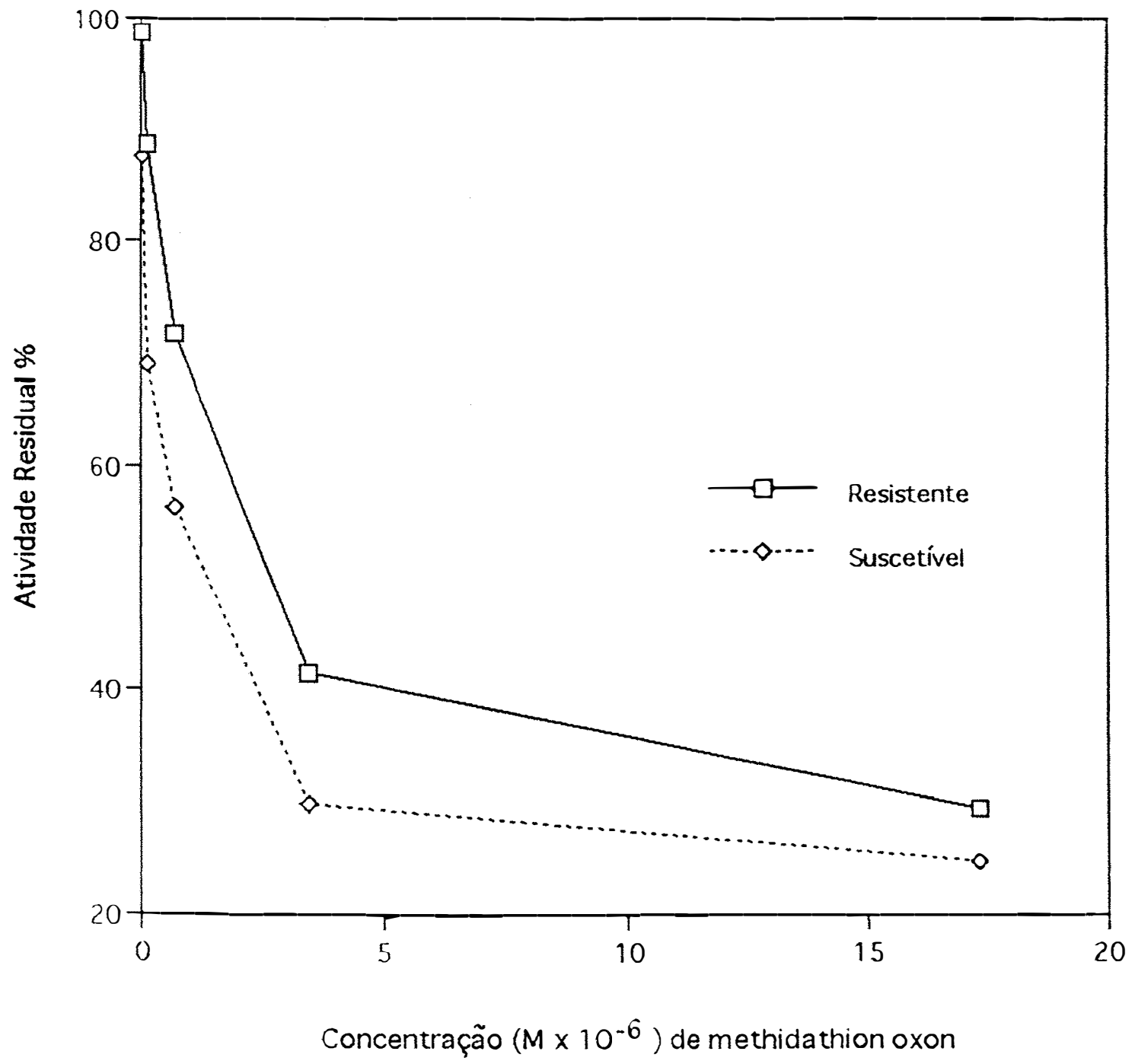

Figura 2. Inibição de acetilcolinesterase por metidation oxon em homogeneizados de fềmeas de Amblyseius womersleyi, das populações suscetível e resistente. 
A insensibilidade do alvo de ação é um mecanismo relativamente comum em ácaros tetraniquídeos, carrapatos e diversas espécies de insetos (Smissaert, 1964; Wharton \& Roulston, 1970; Voss, 1980; Hama, 1983; Oppenoorth, 1985; Guedes \& Dover, 1997), havendo porém, poucos casos conhecidos em ácaros fitoseídeos (Fournier et al., 1985). Estudos com acetilcolinesterases de A. fallacis (Motoyama et al., 1971) e P. persimilis (Fournier et al.. 1987a) mostraram que as taxas de inibição por "formas oxon" de organofosforados eram semelhantes para as populações resistente e suscetível das duas espécies. Entretanto, a resistência de $T$. pyri a paration estava relacionada com a redução da sensibilidade de acetilcolinesterase (Van de Baan et al., 1985).

Anber \& Overmmeer (1988) observaram uma enorme diferença entre as acetilcolinesterases das populações suscetível e resistente de $A$. potentillae, onde a constante de inibição $\left(k_{\mathrm{i}}\right)$ de $\mathrm{ACoE}$ da população resistente de $A$. potentillae foi 781 vezes menor para propoxur e 311 vezes menor para paraoxon, em relação a da população suscetível.

\subsection{Penet ração cuticular}

A avaliação da penetração cuticular de $\left[{ }^{14} \mathrm{C}\right]$-metidation em $A$. womersleyi, através da análise dos níveis de radioatividade presentes na cutícula, mostrou que cada lote de 100 fềmeas da população resistente recebeu aproximadamente $17,7 \mathrm{pg}$ de metidation durante $\mathrm{o}$ tratamento. A quantidade de metidation remanescente na cutícula dos ácaros resistentes avaliados 30 min após o tratamento foi de $6,59 \mathrm{pg}$, chegando a 3,5 pg após uma hora. (Figura 3). Esta redução da quantidade de inseticida na cutícula dos ácaros que foram lavados 30 ou 60 min após o tratamento, em relação à quantidade inicial, seria devido à penetração do inseticida no interior do corpo dos ácaros, considerando-se que o hexano seria capaz de remover apenas o inseticida remanescente na parte externa do corpo dos mesmos.

As taxas de absorção de metidation para os primeiros 60 minutos foram estatisticamente semelhantes para as duas populações (Tabela 10). 


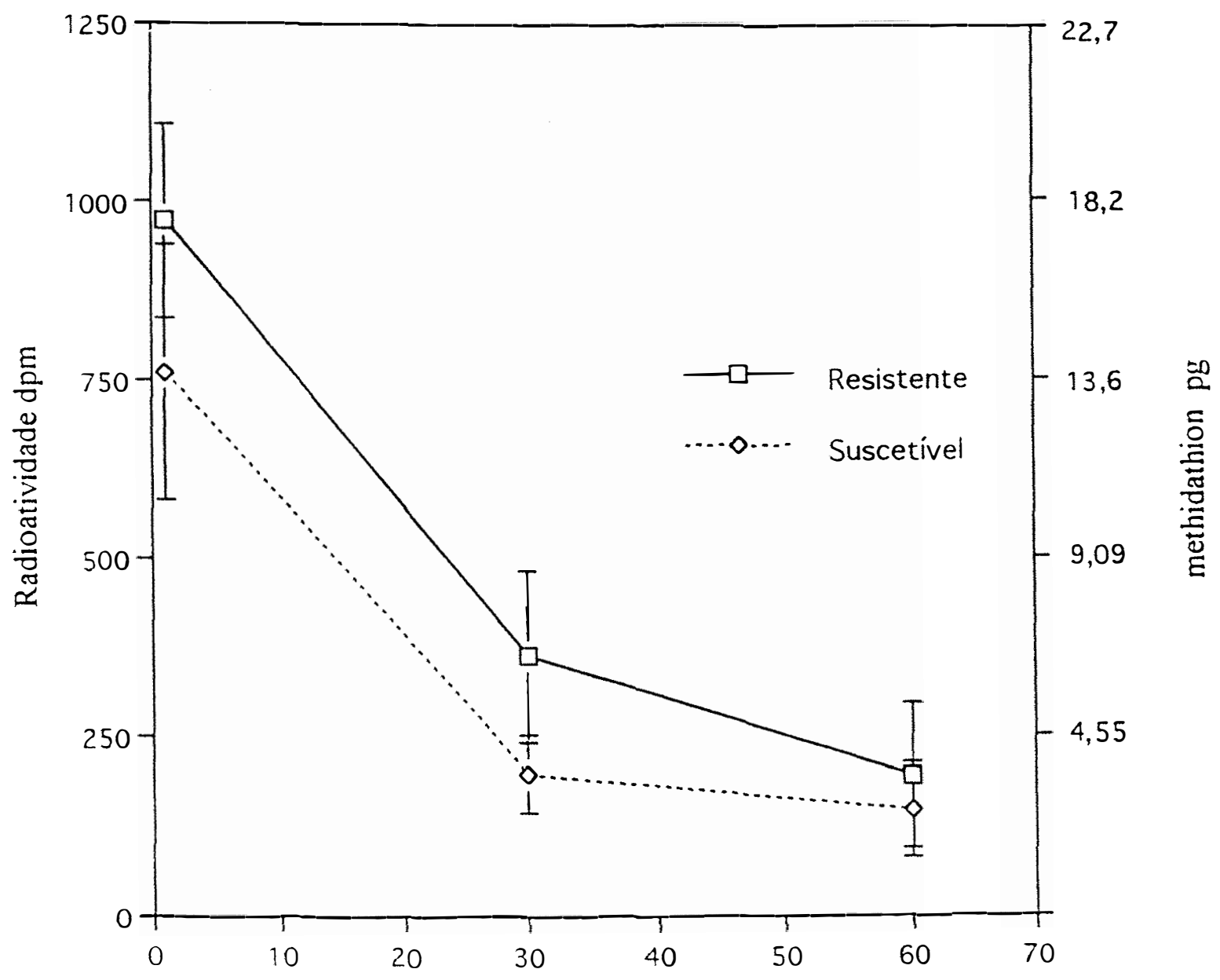

minutos após o tratamento

Figura 3. $\left[{ }^{14} \mathrm{C}\right]$-metidation detectado sobre a cutícula de Amblyseius womersleyi, em diferentes periodos após o tratamento por mergulho de fêmeas adultas das populações suscetível (S) e resistente $(\mathrm{R})$ em solução inseticida. Média e desvio padrão das quantidades do inseticida. 
Tabela 10. $\left[{ }^{14} \mathrm{C}\right]$-metidation detectado sobre a cutícula de Amblyseius womersleyi, em diferentes períodos após o tratamento por mergulho de fềmeas adultas das populações resistente e suscetível em solução inseticida. Radioatividade (dpm) detectada no líquido resultante da lavagem dos ácaros com hexano e desvio padrão.

\begin{tabular}{ccl}
\hline $\begin{array}{c}\text { Tempo após tratamento } \\
\text { (minutos) }\end{array}$ & População & Radioatividade (dpm) \\
\hline 1 & $\mathrm{~S}$ & $760,3 \pm 178,4$ \\
& $\mathrm{R}$ & $973,1 \pm 137,3$ n.s. ${ }^{1}$ \\
30 & $\mathrm{~S}$ & $198,9 \pm 53,3$ \\
& $\mathrm{R}$ & $362,6 \pm 120.5$ n.s. \\
& & \\
60 & $\mathrm{~S}$ & $147,2 \pm 65,9$ \\
& $\mathrm{R}$ & $194,2 \pm 99,9$ n.s. \\
\hline
\end{tabular}

${ }^{1}$ n.s. - não significante ao nível de $5 \%$ pelo teste $t$. 
Estes resultados indicam que a penetração cuticular não estaria envolvida na resistência deste ácaro predador à metidation.

Fournier et al. (1987a) também observaram que a penetração cuticular não era um mecanismo importante na resistência de uma população de $P$. persimilis a metidation. Resultados semelhantes foram obtidos por Motoyama et al. (1971), estudando a resistência de $A$. fallacis a azinfós-metílico.

Embora a penetração não tenha se mostrado importante na resistência destes fitoseídeos, Hirai et al. (1973) mencionaram uma diferença significativa entre as taxas de penetração de $\left[{ }^{32} \mathrm{P}\right]$-dimetoato em duas populações de $P$. citri. A taxa de penetração deste inseticida foi aproximadamente 4 vezes maior na população suscetível. Schnitzerling et al. (1983) também reportaram que este mecanismo estava associado à resistência de Boophilus microplus (Can.) a piretróides.

\subsection{Metabolismo "in vitro" de metidation}

A degradação de $\left[{ }^{14} \mathrm{C}\right]$-metidation em metabólitos solúveis em água, pelas frações solúvel e microssomal obtidas dos ácaros predadores, é apresentada na Tabela 11. No caso da fração solúvel, com ou sem a adição do cofator GSH (glutatiom), não houve diferença no metabolismo entre as populações $\mathrm{S}$ e $\mathrm{R}$ do fitoseídeo, embora tenha sido observada maior taxa de metabolismo de metidation para a fração solúvel, na presença de GSH, para as duas populações de ácaros.

Este fato indica que provavelmente as GSH transferases não apresentam importância significativa nesta resistência.

Entretanto, se a pesquisa fosse baseada apenas em testes com sinergistas poderia-se inferir que as S-transferases de glutatiom estariam parcialmente envolvidas na resistência de $A$. womersleyi a metidation, devido ao efeito sinergístico do tratamento com DEM (inibidor de GSH transferases) na toxicidade de metidation, com redução da razão de resistência de 303 para 94,9 vezes (Tabela 5). Uma possível explicação para esta redução seria que o sinergista DEM também apresenta efeito inibidor sobre as oxidases com funções múltiplas (Fournier et al., 1987a). 
Tabela 11. Metabólitos solúveis em água após a incubação de $\left[{ }^{14} \mathrm{C}\right]$-metidation por $5 \mathrm{~h} \mathrm{em}$ diferentes frações subcelulares de ácaros suscetíveis $(\mathrm{S})$ e resistentes $(\mathrm{R})$ de Amblyseius womersleyi.

\begin{tabular}{lcc}
\hline \multicolumn{1}{c}{ Extrato } & População & $\begin{array}{c}\text { Metabolismo médio } \\
\text { por } 100 \text { fềmeas } \\
\text { (pmol) }\end{array}$ \\
\hline Fração solúvel sem cofator & $\mathrm{S}$ & $0,75 \pm 0,30$ \\
& $\mathrm{R}$ & $0,73 \pm 0,12$ n.s. \\
Fração solúvel com GSH & $\mathrm{S}$ & $2,82 \pm 0,46$ \\
& $\mathrm{R}$ & $3,19 \pm 0,68$ n.s. \\
Fração microssomal com NADPH & $\mathrm{S}$ & $3,43 \pm 0,25$ \\
& $\mathrm{R}$ & $5,08 \pm 0,34 \mathrm{s.}$ \\
\hline
\end{tabular}

${ }^{1} \mathrm{~s}$ - diferença significativa ao nível de $5 \%$ pelo teste $t$, n.s. - não significativo. 
Quanto à fração microssomal, na qual foi adicionada NADPH, houve diferença significativa no metabolismo do inseticida entre as populações $\mathrm{R}$ e $\mathrm{S}$ de $A$. womersleyi. A fração obtida dos ácaros resistentes apresentou uma taxa de metabolismo $48 \%$ superior a dos ácaros suscetíveis. O NADPH foi utilizado para restituir a atividade das oxidases microssomais (ofin) desta fração (Chopade \& Dauterman, 1981).

Estes resultados confirmam os dados obtidos nos experimentos com sinergistas (Testes 1 e 2), indicando que as oxidases com funções múltiplas estão envolvidas nesta resistência de $A$. womersleyi a metidation.

A importância das monooxigenases do citocromo P-450 na resistência de vários insetos a pesticidas é bem conhecida (Wilkinson, 1983; Brattsten et al., 1986; Kasai et al., 1998). A contribuição das enzimas microssomais para resistência de ácaros tem sido verificada através de estudos de metabolismo "in vitro" (Saito et al., 1983; Foumier et al., 1987a; Hatano et al., 1992) ou mais comumente, pela forma indireta, avaliando-se o efeito sinergístico de inibidores de monooxigenases, como PBO, em bioensaios de toxicidade (Roush \& Plapp, 1982; Scott et al. 1983; Vidal \& Kreiter, 1995).

No caso de ácaros da família Phytoseiidae, são raros os trabalhos sobre metabolismo "in vitro" de pesticidas, sendo que na maioria dos casos estudados a resistência estava associada a S-transferases de glutatiom (Motoyama et al. ,1971; Foumier et al., 1985) ou esterases (Anber \& Oppenoorth, 1989). Assim sendo, são poucas as informações existentes sobre o metabolismo de pesticidas em ácaros predadores, envolvendo oxidases microssomais.

Embora a diferença na taxa de metabolismo entre as populações $\mathrm{S}$ e $\mathrm{R}$ de $A$. womersleyi não tenha sido elevada (48 \%), pequenas diferenças no metabolismo enzimático podem estar associadas a altas taxas de resistência, principalmente quando um alvo de ação menos sensivel está envolvido nesta resistência (Oppenoorth, 1985).

Fournier et al. (1987a) observaram uma diferença de 2,9 vezes entre as taxas de metabolismo de metidation nas populações resistente e suscetivel de $P$. persimilis, sendo que a razão de resistência era da ordem de centenas de vezes. Neste caso, a desintoxicação pelas transferases de glutatiom era o principal mecanismo envolvido nesta resistência. 


\subsubsection{Concentração de proteína}

Este teste mostrou que não havia diferença estatística entre as concentrações de proteína de ambas as populações estudadas. As concentrações de proteína no sobrenadante (10.000 $\mathrm{g}$ por 10 minutos) foram respectivamente de $0,46 \pm 0,04 \mathrm{mg} / \mathrm{ml} \mathrm{e} 0,49 \pm 0,06$ $\mathrm{mg} / \mathrm{ml}$, para as populações $\mathrm{S}$ e $\mathrm{R}$ do fitoseídeo. Pelo fato de não ter sido observada nenhuma diferença significativa nesta avaliação, as diferenças detectadas no metabolismo não podem ser atribuídas a diferenças no tamanho ou no teor de proteínas dos ácaros destas populações.

\subsection{Testes toxicológicos com diferentes pesticidas}

Os resultados dos bioensaios com 8 diferentes pesticidas, utilizando as populações resistente e suscetível de $A$. womersleyi, são apresentados na Tabela 12. Este é o primeiro estudo sobre a toxicidade de diferentes pesticidas em uma população de $A$. womersleyi selecionada para resistência a metidation.

As maiores razões de resistência (RR) foram observadas para os inseticidas metidation, acefato e malation, para os quais a população $\mathrm{R}$ mostrou-se respectivamente 311; 20,4 e 13,1 vezes mais resistente que a população $S$.

Embora esta população, selecionada para resistência a metidation, tenha se mostrado mais resistente aos inseticidas organofosforados acefato e malation, esta possível resistência cruzada praticamente não foi observada para os outros organofosforados, clorpirifós e diclorvós. Para estes inseticidas, as RR foram inferiores a 1,8 vezes.

Comparando-se estes 2 produtos, observou-se que $A$. womersleyi se mostrou mais tolerante a diclorvós, cuja $\mathrm{CL}_{50}$ foi igual ou superior a $163 \mathrm{ppm}$, mesmo na população $\mathrm{S}$. A $\mathrm{CL}_{50}$ de clorpirifós foi igual ou inferior a 4,0 ppm, nas duas populações do fitoseídeo.

Nenhuma resistência cruzada foi observada para o inseticida piretróide bifenthrin, que se mostrou altamente tóxico a $A$. womersleyi, com $\mathrm{CL}_{50}$ inferior a $1 \mathrm{ppm}$, em ambas as populações. 
Tabela 12. Testes toxicológicos com diferentes pesticidas utilizando as populações resistente (R) e suscetível (S) de Amblyseius womersleyi. Número total de ácaros para a obtenção das curvas de concentração-mortalidade; estimativa da $\mathrm{CL}_{50}$ (ppm) e intervalo de confiança (I.C.) a 95\%; coeficiente angular e erro padrão da média (EPM); Qui-quadrado $\left(\chi^{2}\right)$; grau de liberdade (G.L.); razão de resistência (RR).

\begin{tabular}{|c|c|c|c|c|c|c|c|}
\hline Pesticida & $\begin{array}{l}\text { Popu- } \\
\text { lação }\end{array}$ & $\begin{array}{l}\text { Número } \\
\text { Ácaros } \\
\text { (Conc.) }\end{array}$ & $\begin{array}{c}\mathrm{CL}_{50} \\
(95 \% \text { I.C. })\end{array}$ & $\begin{array}{c}\text { Coeficiente } \\
\text { Angular } \\
\pm \text { EPM } \\
\end{array}$ & $\chi^{2}$ & G.L. & $\mathrm{RR}$ \\
\hline \multirow[t]{2}{*}{ metidation } & ${ }^{3} \mathrm{R}$ & 373 & $\begin{array}{c}548 \\
(486-624)\end{array}$ & $3,31 \pm 0,10$ & 0,61 & 3 & 311 \\
\hline & ${ }^{2} S$ & 449 & $\begin{array}{c}1,76 \\
(1,50-2,09)\end{array}$ & $2,15 \pm 0,14$ & 3,68 & 4 & - \\
\hline \multirow[t]{2}{*}{ acefato } & $\mathrm{R}$ & 450 & $\begin{array}{c}149 \\
(127-177)\end{array}$ & $1,99 \pm 0,14$ & 4,49 & 4 & 20,4 \\
\hline & $\mathrm{S}$ & 458 & $\begin{array}{c}7.32 \\
(6,15-9,05)\end{array}$ & $2,07 \pm 0,20$ & 3,87 & 4 & - \\
\hline \multirow[t]{2}{*}{ malation } & $\mathrm{R}$ & 381 & $\begin{array}{c}152 \\
(134-174)\end{array}$ & $3,31 \pm 0,19$ & 0,46 & 3 & 13,1 \\
\hline & $S$ & 530 & $\begin{array}{c}11,6 \\
(9,47-14,6)\end{array}$ & $1,52 \pm 0,16$ & 4,28 & 5 & - \\
\hline \multirow[t]{2}{*}{ clorpirifós } & $\mathrm{R}$ & 456 & $\begin{array}{c}3,67 \\
(3,40-4,00)\end{array}$ & $4,39 \pm 0,33$ & 5,75 & 4 & 1,72 \\
\hline & $S$ & 371 & $\begin{array}{c}2,14 \\
(1,88-2,44)\end{array}$ & $3,07 \pm 0,10$ & 0,81 & 3 & - \\
\hline \multirow[t]{2}{*}{ diclorvós } & $\mathrm{R}$ & 529 & $\begin{array}{c}315 \\
(268-373)\end{array}$ & $2,13 \pm 0,18$ & 6,92 & 5 & 1,64 \\
\hline & S & 524 & $\begin{array}{c}191 \\
(163-228)\end{array}$ & $2,13 \pm 0,13$ & 4,64 & 5 & $=$ \\
\hline \multirow[t]{2}{*}{ bifenthrin } & $\mathrm{R}$ & 371 & $\begin{array}{c}0,59 \\
(0,50-0,71)\end{array}$ & $2,10 \pm 0,10$ & 0,95 & 3 & 1,13 \\
\hline & S & 376 & $\begin{array}{c}0,52 \\
\left(0,44^{-}-0,61\right)\end{array}$ & $2,23 \pm 0,20$ & 2,65 & 3 & - \\
\hline \multirow[t]{2}{*}{ fluvalinate } & $R$ & 448 & $\begin{array}{c}7,50 \\
(6,20-8,92)\end{array}$ & $1,81 \pm 0,13$ & 3,10 & 4 & 1,49 \\
\hline & S & 450 & $\begin{array}{c}5,02 \\
(4,27-5,92)\end{array}$ & $2,02 \pm 0,17$ & 3,72 & 4 & - \\
\hline \multirow[t]{2}{*}{ piridaben } & $\mathrm{R}$ & 451 & $\begin{array}{c}41,1 \\
(35,6-48,4)\end{array}$ & $2,57 \pm 0,26$ & 3,76 & 4 & 2,20 \\
\hline & $S$ & 454 & $\begin{array}{c}18,7 \\
(16,0-21,9)\end{array}$ & $2,14 \pm 0,25$ & 6,27 & 4 & - \\
\hline
\end{tabular}

${ }^{\prime} \mathrm{RR}=$ Razão de Resistência $=\mathrm{CL}_{50}$ resistente/ $\mathrm{CL}_{50}$ suscetível

${ }^{2}$ População suscetivel $=$ selecionada para suscetibilidade a metidation $(2 \mathrm{ppm})$

${ }^{3}$ População resistente $=$ selecionadada para resistência a metidation $(500 \mathrm{ppm})$ 
O outro piretróide, fluvalinate, mostrou-se ligeiramente menos tóxico que bifenthrin, embora as $\mathrm{CL}_{50}$ tenham sido inferiores a $10 \mathrm{ppm}$, para ambas as populações deste predador.

A alta toxicidade de piretróides a fitoseídeos também foi mencionada em diversos outros trabalhos (Croft \& Whalon, 1982; Hamamura, 1987; Zacharda \& Hlùchy, 1991; Yamamoto et al., 1992; Reis et al., 1998).

Com relação ao acaricida piridaben, do grupo químico das piridazinonas, a população $\mathrm{R}$ foi 2,2 vezes mais resistente ao produto, em relação à $\mathrm{S}$. $A \mathrm{CL}_{50}$ foi de 41,1 ppm, para a população $R$.

Embora a população $\mathrm{R}$ tenha se mostrado significativamente mais resistente a diversos produtos testados, observou-se que as oxidases com funções múltiplas possivelmente associadas a esta resistência não auxiliaram ou afetaram pouco a sobrevivência destes predadores, quando expostos a certos piretróides ou mesmo alguns inseticidas organofosforados.

Caso uma população de $A$. womersleyi resistente a metidation já esteja presente na cultura do chá, ou venha a ser introduzida, estas informações podem ser úteis na escolha do produto a ser aplicado, considerando-se que foram testados os principais pesticidas registrados para a cultura no Japão que poderiam ser prejudiciais aos ácaros predadores.

\subsection{Considerações gerais}

A metodologia utilizada neste trabalho possibilitou o estudo dos principais mecanismos envolvidos na resistência de $A$. womersleyi a metidation. Estas técnicas podem ser adaptadas e utilizadas para a análise dos mecanismos de resistência a pesticidas em outros ácaros de importância para a agricultura.

Esta pesquisa serve de subsídio para programas de controle integrado de $T$. kanzawai e outros ácaros fitófagos predados por $A$. womersleyi, trazendo informações sobre o potencial do uso das populações deste fitoseídeo resistentes a metidation.

Os agentes de controle biológico podem contribuir para a redução da freqüência de ácaros fitófagos resistentes (Omoto, 1998), podendo assim dificultar o desenvolvimento de 
resistência a pesticidas nestas pragas. Desta forma, as pesquisas com $A$. womersleyi podem ser úteis para o manejo da resistência de T. kanzawai a pesticidas.

Ainda são necessários diversos estudos sobre a resistência de $A$. womersleyi a metidation e outros pesticidas. Estudos mais aprofundados sobre o metabolismo enzimático de pesticidas em ácaros predadores resistentes podem servir para o desenvolvimento de testes rápidos "in vitro", para facilitar a detecção e o monitoramento da resistência destes ácaros no campo. Estudos sobre a estabilidade da resistência a pesticidas em condições de campo, também seriam importantes. Estas pesquisas poderiam ser muito úteis para um aproveitamento mais adequado das populações resistentes de $A$. womersleyi em programas de manejo integrado de pragas. 


\section{CONCLUSÕES}

Os resultados obtidos neste trabalho permitem concluir que:

Um aumento na degradação oxidativa está envolvido na resistência da população $R$ de $A$. womersleyi a metidation.

Uma alteração no alvo de ação (redução na sensibilidade de acetilcolinesterase) também se mostra envolvida nesta resistência, porém com importância secundária.

A redução na penetração cuticular não apresenta importância significativa na resistência de $A$. womersleyi ao inseticida organofosforado metidation.

A população de $A$. womersleyi, selecionada para o aumento de resistência a metidation, mostra-se mais resistente a alguns outros inseticidas, tais como acefato e malation, em relação à população suscetível. 


\section{REFERÊNCIAS BIBLIOGRÁFICAS}

ANBER, H.A.I.; OPPENOORTH, F.J. A mutant esterase degrading organophosphates in a resistant strain of the predacious mite Amblyseius potentillae (Garman). Pesticide Biochemistry and Physiology, v.33, p.283-297, 1989.

ANBER, H.A.I.; OVERMEER, W.P.J. Resistance to organophosphates and carbamates in the predacious mite Amblyseius potentillae (Garman) due to insensitive acetylcholinesterase. Pesticide Biochemistry and Physiology, v.31, p.91-98, 1988.

ANDRADE, C.F.S. de; BRANCO JR, A.C. Methods for field detection of resistance to temephos in simuliids. Larval esterase level and topical application of the insecticide to adults. Memórias do Instituto Oswaldo Cruz, v.85, n.3, p.291-297, 1990.

BAKER, J.E.; ARBOGAST, R.T. Malation resistance in field strains of the warehouse pirate bug (Heteroptera: Anthocoridae) and a prey species Tribolium castaneum (Coleoptera: Tenebrionidae). Journal of Economic Entomology, v.88, n.2, p.241245, 1995.

BLOMMERS, L.H.M. Integrated pest management in European apple orchards. Annual Review of Entomology, v.39, p.213-241, 1994.

BOURGUET, D.; CAPELA, R.; RAYMON, M. An insensitive acetylcholinesterase in Culex pipiens (Diptera: Culicidae) from Portugal. Journal of Economic Entomology, v.89, n.5, p.1060-1066, 1996. 
BRADFORD, M.M. A rapid and sensitive method for the quantification of microgram quantities of protein utilizing the principle of protein-dye binding. Analytical Biochemistry, v.72, p.248-254, 1976.

BRATTSTEN, L.B.; HOLYOKE, C.W. JR; LEEPER, J.R; RAFFA, K.F. Insecticide resistance: Challenge to pest managemente and basic research. Science, v.231, p.1255-1260, 1986.

BROWN, T.M.; BRYSON, P.K.; PAYNE, G.T. Synergism by propynyl aryl ethers in permethrin-resistant tobbaco budworm larvae, Heliothis virescens. Pesticide Science, v.43, p.323-331, 1996.

CAMPANHOLA, C. Resistência de insetos a inseticidas: importância, características e manejo. Jaguariúna: EMBRAPA, CNPDA, 1990. 45p. (Documentos, 11).

CARBONARO, M.A.; MORELAND, D.E.; EDGE, V.E.; MOTOYAMA, N.; ROCK, G.C.; DAUTERMAN, W.C. Studies on the mechanism of cyhexatin resistance in the twospotted spider mite, Tetranychus urticae (Acari: Tetranychidae). Journal of Economic Entomology, v.79, p.576-579, 1986.

CASIDA, J.E. Mixed-function oxidase involvement in the biochemistry of insecticide synergists. Journal of Agricultural and Food Chemistry, v.18, p.753-772, 1970.

CHANT, D.A. The Phytoseiidae. In: HELLE, W.; SABELIS, M.W. (Ed.) Spider mites: their biology, natural enemies, and control. Amsterdam: Elsevier, 1985. v.1b, p.3-32.

CHOPADE, H.M.; DAUTERMAN, W.C. Studies on the in vitro metabolism of methidathion by rat and mouse liver. Pesticide Biochemistry and Physiology, v.15, p.105-119, 1981. 
CROFT, B.A.; BARNES, M.M. Comparative studies on four strains of Typhlodromus occidentalis: VI. Persistence of insecticide resistant strains in an apple orchard ecosystem. Journal of Economic Entomology, v.65, p.211 -216, 1972.

CROFT, B.A.; BROWN, W.A. Responses of arthropod natural enemies to insecticides. Annual Review of Entomology, v.20, p.285-335, 1975.

CROFT, B.A.; MORSE, J.G. Research advances on pesticide resistance in natural enemies. Entomophaga, v.24, p.3-11, 1979.

CROFT, B.A.; STRICKLER, K.A. Natural enemy resistance to pesticides: documentation, characterization, theory and application. In: GEORGHIOU, G.P.; SAITO, T. (Ed.) Pest resistance to pesticides. New York: Plenum Press, 1983. p. 669-702.

CROFT, B.A.; VAN DE BAAN, H.E. Ecological and genetic factors influencing evolution of pesticide resistance in tetranychid and phytoseiid mites. Experimental \& Applied Acarology, v. 4, p.277-300, 1988.

CROFT, B.A.; WHALON, M.E. Selective toxicity of pyrethroid insecticides to arthropod natural enemies and pests of agricultural crops. Entomophaga, v.27, p.3-21, 1982.

DENNEHY, T.J.; GRANETT, J.; LEIGH, T.F. Relevance of slide-dip and residual bioassay comparisons to detection of resistance in spider mites. Journal of Economic Entomology, v.76, p.1225-1230, 1983.

DEVONSHIRE, A.L. The properties of a carboxylesterase from the peach-potato aphid, Myzus persicae (Sulz.), and its role in conferring insecticide resistance. The Biochemical Journal, v.167, p.675-683, 1977. 
DUNLEY, J.E.; MESSING, R.H.; CROFT, B.A. Levels and genetics of organophosphate resistance in Italian and Oregon biotypes of Amblyseius andersoni (Acari: Phytoseiidae). Journal of Economic Entomology, v.84, n. 3, p. 750-755, 1991.

ELLMANN, G.L.; COURTNEY, K.D.; ANDRES JR., V.; FEATHERSTONE, R.M. A new and rapid colorimetric determination of acetylcholinesterase activity. Biochemical Pharmacology, v.7, p.88, 1961.

ERKILIK, L.B.; UYGUN, N. Studies on the effects of some pesticides on white peach scale, Pseudaulacaspis pentagona (Targ. Tozz.) (Homoptera: Diaspididae) and its side-effects on two common scale insect predators. Crop Protection, v.16, n.1, p.69-72, 1997.

FAO. Recommended methods for the detection and measurement of resistance of agricultural pests to pesticides. Method for phytoseiid predatory mites. FAO Plant Protection Bulletin, v.32, n.1, p.25-27, 1984.

FERGUSSON-KOLMES, L.A.; SCOTT, J.G.; DENNEHY, T.J. Dicofol resistance in Tetranychus urticae (Acari: Tetranychidae): cross-resistance and pharmacokinetics. Journal of Economic Entomology, v.84, n.1, p.41-48, 1991.

FIELD, R.P. Control of the two-spotted mite in a Victorian peach orchard with an introduced, insecticide-resistant strain of the predatory mite Typhlodromus occidentalis Nesbitt (Acarina: Phytoseiidae). Australian Journal of Zoology, v.26, p.519-527, 1978.

FINNEY, D.J. Probit analysis. 3. ed. London: Cambridge University Press, 1971. 315p. 
FOURNIER, D.; PRALAVORIO, M; BERGE, J.B.; CUANY, A. Pesticide resistance in Phytoseiidae. In: HELLE, W.; SABELIS, M.W. (Ed.) Spider mites: their biology, natural enemies, and control. Amsterdam: Elsevier, 1985. v. 1b, p.423-432.

FOURNIER, D.; CUANY, A.; PRALAVORIO, M.; BRIDE, J.M.; BERGE, J.B. Analysis of methidathion resistance mechanism in Phytoseiulus persimilis A.H. Pesticide Biochemistry and Physiology, v.28, n.2, p.271-278, 1987a.

FOURNIER, D.; PRALAVORIO, M.; CUANY, A.; BERGE, J.B. Genetic analysis of methidathion resistance in Phytoseiulus persimilis (Acari: Phytoseiidae). Journal of Economic Entomology, v.81, n.4, p.1008-1013, 1988.

FOURNIER, D.; PRALAVORIO, M.; TROTTIN-CAUDAL, Y.; COULON, J.; MALEZIEUX, S.; BERGE, J.B. Sélection artificielle pour la résistance au methidathion chez Phytoseiulus persimilis A.H. Entomophaga, v.32, n.2, p.209-219, $1987 b$.

GUEDES, R.N.C.; DOVER, B.A. Acetylcholinesterase inhibition in organophosphateresistant Rhyzopertha dominica (F.) (Coleoptera: Bostrichidae). Anais da Sociedade Entomológica do Brasil, v.26, n.3, p.561-564, 1997.

GRUYS, P. Hits and misses. The ecological approach to pest control in orchards. Entomologia Experimentalis et Applicata, v.31, p.70-87, 1982.

HAMA, H. Resistance to insecticides due to reduced sensitivity of acetylcholinesterase. In: GEORGHIOU, G.P.; SAITO, T. (Ed.) Pest resistance to pesticides. New York: Plenum Press, 1983. p. 299-331. 
HAMAMURA, T. Biological control of Kanzawa spider mite, Tetranychus kanzawai Kishida, in tea fields by the predacious mite, Amblyseius longispinosus (Evans), which is resistant to chemicals (Acarina; Tetranychidae, Phytoseiidae). Japan Agricultural Research Quarterly, v.21, n.2, p.109-116, 1987.

HART, G.J.; O' BRIEN, R.D. Recording spectrophotometric method for determination of dissociation and phosphorylation constants for the inhibition of acetylcholinesterase by organophosphates in the presence of substrate. Biochemistry, v.12, n.15, p.2940$2945,1973$.

HATANO, R.; SCOTT, J.G.; DENNEHY, T.J. Enhanced activation is the mechanism of negative cross-resistance to chlorpyrifos in the dicofol-IR strain of Tetranychus urticae (Acari: Tetranychidae). Journal of Economic Entomology, v.85, n.4, p.1088-1091, 1992.

HIRAI, K.; MIYATA, T.; SAITO, T. Penetration of ${ }^{32} \mathrm{P}$-dimethoate into organophosphate resistant and susceptible citrus red mite, Panonychus citri McGregor (Acarina: Tetranychidae). Applied Entomology and Zoology, v.8, n.3, p.183-190, 1973.

HO, C.C.; LO, K.C.; CHEN, W.H. Comparative biology, reproductive compability, and geographical distribution of Amblyseius longispinosus and A. womersleyi (Acari: Phytoseiidae). Environmental Entomology, v.24, n.3, p.601-607, 1995.

HOY, M.A. Recent advances in genetics and genetic improvement of the Phytoseiidae. Annual Review of Entomology, v.30, p.345-370, 1985.

HOY, M.A. Pesticide resistance in arthropod natural enemies: variability and selection responses. In: ROUSH, R.T.; TABASHNIK, B.E. (Ed.) Pest resistance in arth ropods. New York: Chapman and Hall. 1990. p. 203-236. 
HOY, M.A.; KNOP, N.F. Selection for and genetic analysis of permethrin resistance in Metaseiulus occidentalis: genetic improvement of biological control agent. Entomologia Experimentalis et Applicata, v.30, p.10-18, 1981.

HOY, M.A.; OUYANG, Y.L. Selection of the western predatory mite, Metaseiulus occidentalis (Acari: Phytoseiidae), for resistance to abamectin. Journal of Economic Entomology, v.82, p.35-40,1989.

HOY, M.A.; FLAHERTY, D.L.; PEACOCK, W.; CULVER, D. Vineryard and laboratory evolutions of methomyl, dimethoate, and permethrin for grape pest management program in the San Joaquin Valley of California. Journal of Economic Entomology, v.72, p.250-255, 1979.

HUSSEY, N.W.; SCOPES, N.E.A. Greenhouse vegetables. In: HELLE, W.; SABELIS, M.W. (Ed.) Spider mites: their biology, natural enemies, and control. Amsterdam: Elsevier, 1985. v.1b, p.285-298.

JAMES, D.G.; OMALLEY, K.J. Control of redlegged earth mite Halotydeus destructor on bare earth. Plant Protection Quarterly, v.7, n.1, p.10-11, 1992.

KASAI, S.; WEERASHINGHE, I.S.; SHONO, T. P450 monooxygenases are an important mechanism of permethrin resistance in Culex quinquefasciatus Say larvae. Archives of Insect Biochemistry and Physiology, v. 37, p.47-56, 1998.

KAWAI, A. Prospect for integrated pest management in tea cultivation in Japan. Japan Agricultural Research Quarterly, v. 31, p.213-217, 1997. 
KIM, D.I.; LEE, S.C.; KIM, S.S. Biological characteristics of Amblyseius womersleyi Schicha (Acarina: Phytoseiidae) as a predator of Tetranychus kanzawai Kishida (Acarina: Tetranychidae). Korean Journal of Applied Entomology, v.35, n.1, p.3844, 1996a.

KIM, D.I.; PARK, J.D.; KIM, S.S.; PARK, I.J.; KIM, S.C. Biological control of tea red spider mite, Tetanychus kanzawai, by predaceous mite, Amblyseius womersleyi in tea fields. RDA Journal of Agricultural S cience, v.38, p.203-210, $1996 \mathrm{~b}$.

KUWAHARA, M.; MIYATA, T.; SAITO, T.; ETO, M. Activity and substrate specificity of esterase associated with organophosphorus insecticide resistance in kanzawa spider mite, Tetranychus kanzawai Kishida (Acarina: Tetranychidae). Applied Entomology and Zoology, v.17, n.1, p.82-91, 1982.

LAKASA, A.; MARTINEZ, M.C.; TORRES, J. Efecto de los tratamientos en el control de las poblaciones del acaro de las yemas (Aceria sheldoni Ewing) del limonero. Boletin de Sanidad Vegetal Plagas, v.16, n.1, p. 305-316, 1990.

MIYATA, T. Detection and monitoring methods for resistance in arthropods based on biochemical characteristics. In: GEORGHIOU, G.P.; SAITO, T. (Ed.) Pest resistance to pesticides. New York: Plenum Press, 1983. p. 99-116.

MIYATA, T.; SAITO, T. Mechanism of malation resistance in green rice leafhopper, Nephotettix cincticeps Uhler (Hemiptera: Deltocephalidae). Journal of Pesticide Science, v.1, p.23-29, 1976.

MOCHIZUKI, M. Insecticide resistance of phytoseiid mite Amblyseius longispinosus (Evans) in tea field. Biochemical Biophysical Research Communications, v.189, n.1, p.675-679, 1992. 
MOCHIZUKI, M. Variations in insecticide susceptibility of the predatory mite, Amblyseius womersleyi Schicha (Acarina: Phytoseiidae), in the tea fields of Japan. Applied Entomology and Zoology, v.29, n.2, p.203-209, 1994.

MOCHIZUKI, M. Development, fecundity, diapause attribute, and reproductive compatibility of a pesticide-resistant strain of the predatory mite Amblyseius womersleyi Schicha (Acari: Phytoseiidae). Japanese Journal of Applied Entomology, v.40, n.2, p.121-126, 1996.

MOCHIZUKI, M. Permethrin resistance and stability in the predatory mite, Amblyseius womersleyi Schicha (Acari: Phytoseiidae). Japanese Journal of Applied Entomology and Zoology, v.41, p.1-5, 1997.

MORAES, G.J. de. Controle biológico de ácaros fitófagos. Informe Agropecuário, v.15, n. 167, p.56-62, 1991.

MORAES, G.J. de. Perspectivas para o uso de predadores no controle de ácaros fitófagos no Brasil. Pesquisa Agropecuária Brasileira, v.27, p.263-270, 1992.

MORAES, G.J. de; McMURTRY, J.A.; DENMARK, H.A. A catalog of the mite family Phytoseiidae: references to taxonomy, synonymy, distribution and habitat. Brasilia: EMBRAPA-DDT, 1986. 353p.

MOTOYAMA, N.; ROCK, G.C.; DAUTERMAN, W.C. Studies on the mechanism of azinphosmethyl resistance on the predaceous mite, Neoseiulus fallacis (T.) (family: Phytoseiidae). Pesticide Biochemistry and Physiology, v.1, p.205-215, 1971.

MOTOYAMA, N.; DAUTERMAN, W.C.; ROCK, G.C. Toxicity of O-alkyl analogues of azinphosmethyl and other insecticides to resistant and susceptible predaceous mites, Amblyseius fallacis. Journal of Economic Entomology, v.70, n.4, p.475-476, 1977. 
MULLIN, C.A.; CROFT, B.A.; STRICKLER, K, MATSUMURA, F.; MILLER, J.R. Detoxification enzyme differences between a herbivorous and predatory mite. Science, v.217, p.1270-1272, 1982.

NOPPUN, V.; SAITO, T.; MIYATA, T. Cuticular penetration of S-fenvarelate in fenvarelate-resistant and susceptible strains of the diamondback moth, Plutella xylostella (L.). Pesticide Biochemistry and Physiology, v.33, p.83-87, 1989.

OPPENOORTH, F.J. Biochemistry and genetics of insecticide resistance. In: KERKUT, G.A.; GILBERT, L.I. (Ed.) Compreensive insect physiology, biochemistry and pharmacology. Oxford: Pergamon, 1985. v.12, p.731-773.

OPPENOORTH, F.J. Biochemistry of insecticide resistance. Pesticide Biochemistry and Physiology, v.22, p.187-193, 1984.

OMOTO, C. Acaricide resistance management of leprosis mite (Brevipalpus phoenicis) in Brazilian citrus. Pesticide Science, v.52, p. 189-191, 1998.

OVERMEER, W.P.J. Toxicological methods. In: HELLE, W. \& SABELIS, M.W. (Ed.) Spider mites: their biology, natural enemies, and control. Vol. 1b. Amsterdam: Elsevier, 1985. v. 1b, p.183-189.

PENMAN, D.R.; WEARING, C.H.; COLYER. E.; THOMAS, W.P. The role of insecticide-resistant phytoseiids in integrated mite control in New Zealand. In: RODRIGUES, J.G. (Ed.) Recent advances in acarology, Vol. 1. New York: Academic Press. 1979. p.59-69. 
PLAPP JR, F.W. Genetics and biochemistry of insecticide resistance in arthropods: prospects for the future. In: NATIONAL RESEARCH COUNCIL. Pesticide resistance: strategies and tactics for management. Washington: National Academic Press. 1986. p.74-85.

PLAPP JR, F.W.; WANG, T.C. Genetic origins of insecticide resistance. In: GEORGHIOU, G.P.; SAITO, T. (Ed.) Pest resistance to pesticides. New York: Plenum Press, 1983. p. 47-70.

REIS, P.R.; CHIAVEGATO, L.G.; MORAES, G.J. de; ALVES, E.B.; SOUSA, E.O. Seletividade de agroquímicos ao ácaro predador Iphiseiodes zuluagai Denmark \& Muma (Acari: Phytoseiidae). Anais da Sociedade Entomológica do Brasil, v.27, n.2, 265-274, 1998.

ROUSH, R.T.; HOY, M.A. Genetic improvement of Metaseiulus occidentalis: selection with methomyl, dimethoate, and carbaryl and genetic analysis of carbaryl resistance. Journal of Economic Entomology, v.74, p.138-141, 1981.

ROUSH, R.T.; PLAPP JR., F.W. Biochemical genetics of resistance to aryl carbamate insecticides in the predaceous mite, Metaseiulus occidentalis. Journal of Economic Entomology, v.75, p.304-307, 1982.

SAITO, T.; TABATA, K., KOHNO, S. Mechanisms of acaricide resistance with emphasis on dicofol. In: GEORGHIOU, G.P.; SAITO. T. (Ed.) Pest resistance to pesticides. New York: Plenum Press, 1983. p. 429-444.

SAKATA, K.; MIYATA, T. Biochemical characterization of carboxylesterase in small brown planthopper Laodelphax striatellus (Fallén). Pesticide Biochemistry and Physiology, v.50, p.247-256, 1994. 
SCHICHA, E. A new predacious species of Amblyseius Berlese from strawberry in Australia, and A. longispinosus (Evans) redescribed (Acari: Phytoseiidae). Journal of the Australian Entomological Society, v.14, p.101-106, 1975.

SCHNITZERLING, H.J.; NOLAN, J.; HUGHES, S. Toxicology and metabolism of some synthetic pyrethroids in larvae of susceptible and resistant strains of the cattle tick Boophilus microplus (Can.). Pesticide Science, v.14, p.64-72, 1983.

SCOTT, J.G.; CROFT, B.A.; WAGNER, S.W. Studies on the mechanism of permethrin resistance in Amblyseius fallacis (Acarina: Phytoseiidae) relative to previous insecticide use on apple. Journal of Economic Entomology, v.76, n. 1, p.6-10, 1983.

SHIH, C.T. Biological control of mulberry spider mites, Tetranychus kanzawai, with augmentation of Amblyseius womersleyi. Special Publication, Taiwan Agricultural Research Institute, v.19, p.21-27, 1985.

SMISSAERT, H.R. Cholinesterase inhibition in spider mites susceptible and resistant to organophophate. Science, v.143, p.129-131, 1964.

SMITH D. Effect of the insect growth regulator buprofezin against citrus pests Coccus viridis (Green) Polyphagotarsonemus latus (Banks) and Aonidiella aurantii (Maskell) and the predatory coccinellid Chilocorus circumdatus Gyllenhal. Plant Protection Quarterly, v.10, n.3, p.112-115, 1995.

STRICKLER, K.A.; CROFT, B.A. Selection for permethrin resistance in the predatory mite, Amblyseius fallacis Garman (Acarina: Phytoseiidae). Entomologia Experimentalis et Applicata, v.31, p.339-345, 1982. 
TABASHNIK, B.E. Evolution of pesticide resistance in predator/prey systems. Bulletin of the Entomological Society of America, v.32, p.1 56-161, 1986.

TAG ELDIN, M.H. A rapid detection of organophosphorus resistance with insensitive acetylcholinesterase in spider mites Tetranychus urticae Koch on cotton. Journal of Applied Entomology, v.110,p.416-420, 1990.

VAN DE BAAN, H.E.; KUIJPERS, L.A.M.; OVERMEER, W.P.J.; OPPENOORTH, F.J. Organophosphorus and carbamate resistance in the predacious mite Typhlodromus pyri due to insensitive acetylcholinesterase. Experimental \& Applied Acarology, v.1, p.3, 1985.

VIDAL, C.; KREITER, S. Resistance to a range of insecticides in the predaceous mite Typhlodromus pyri (Acari: Phytoseiidae): inheritance and physiological mechanisms. Journal of Economic Entomology, v.88, n.5, p.1097-1105, 1995.

VOSS, G. Cholinesterase autoanalysis: a rapid method for biochemical studies on susceptible and resistant insects. Journal of Economic Entomology, v.73, p.189$192,1980$.

WAITE, G.K. Integrated control of Tetranychus urticae in strawberries in South-East Queensland. Experimental \& Applied Acarology, v.5, p.23-32, 1988.

WALKER, G.P.; AITKEN, D.C.G. Non-target effect of sprays to control California red scale (Aonidiella aurantii (Maskell), Hom., Diaspididae) on citrus red mite (Panonychus citri (McGregor), Acari, Tetranychidae). Journal of Applied Entomology, v.120, n.3, p.175-180, 1996.

WHARTON, R.H.; ROULSTON, W.J. Resistance of ticks to chemicals. Annual Review of Entomology, v.15, p.381-404, 1970. 
WLKINSON, C.F. Role of mixed-function oxidases in insecticide resistance. In: GEORGHIOU, G.P.; SAITO, T. (Ed.) Pest resistance to pesticides. New York: Plenum Press, 1983. p.175-205.

YAMAMOTO, P.T.; PINTO, A. de S.; PAIVA, P.E.P.; GRAVENA, S. Seletividade de agrotóxicos aos inimigos naturais de pragas dos citros. Laranja, v.13, n.2, p.709-755, 1992.

YAMAMOTO, A.; YONEDA, H.; HATANO, H.; ASADA, M. Laboratory selections of populations in the citrus red mite, Panonychus citri (McGregor), with hexythiazox and their cross resistance spectrum. Journal of Pesticide Science, v.20, n.4, p.493$501,1995$.

YU, S.J.; NGUYEN, S.N. Insecticide susceptibility and detoxication enzyme activities in permethrin-selected diamondback moths. Pesticide Biochemistry and Physiology, v.56, p.69-77, 1996.

ZACHARDA, M.; HLU̇CHY, M. Long-term residual efficacy of commercial formulations of pesticides to Typhlodromus pyri Scheuten (Acari: Phytoseiidae) inhabiting commercial vineyards. Experimental and Applied Acarology, v. 13, p.27-40, 1991. 